\title{
مستوى الاغتراب الوظيفي لدى قادة المدارس الثانوية الحكومية في مدينة بريدة
}

\author{
أملاك سليمان إبراهيم الصلال \\ جامعة القصيم- المملكة العربية السعودية إناهين \\ malaksallal@hotmail.com
}

\section{علي صالح الشايع}

أستاذ الإدارة والتخطيط التربوي- جامعة القصيم- المملكة العربية السعودية

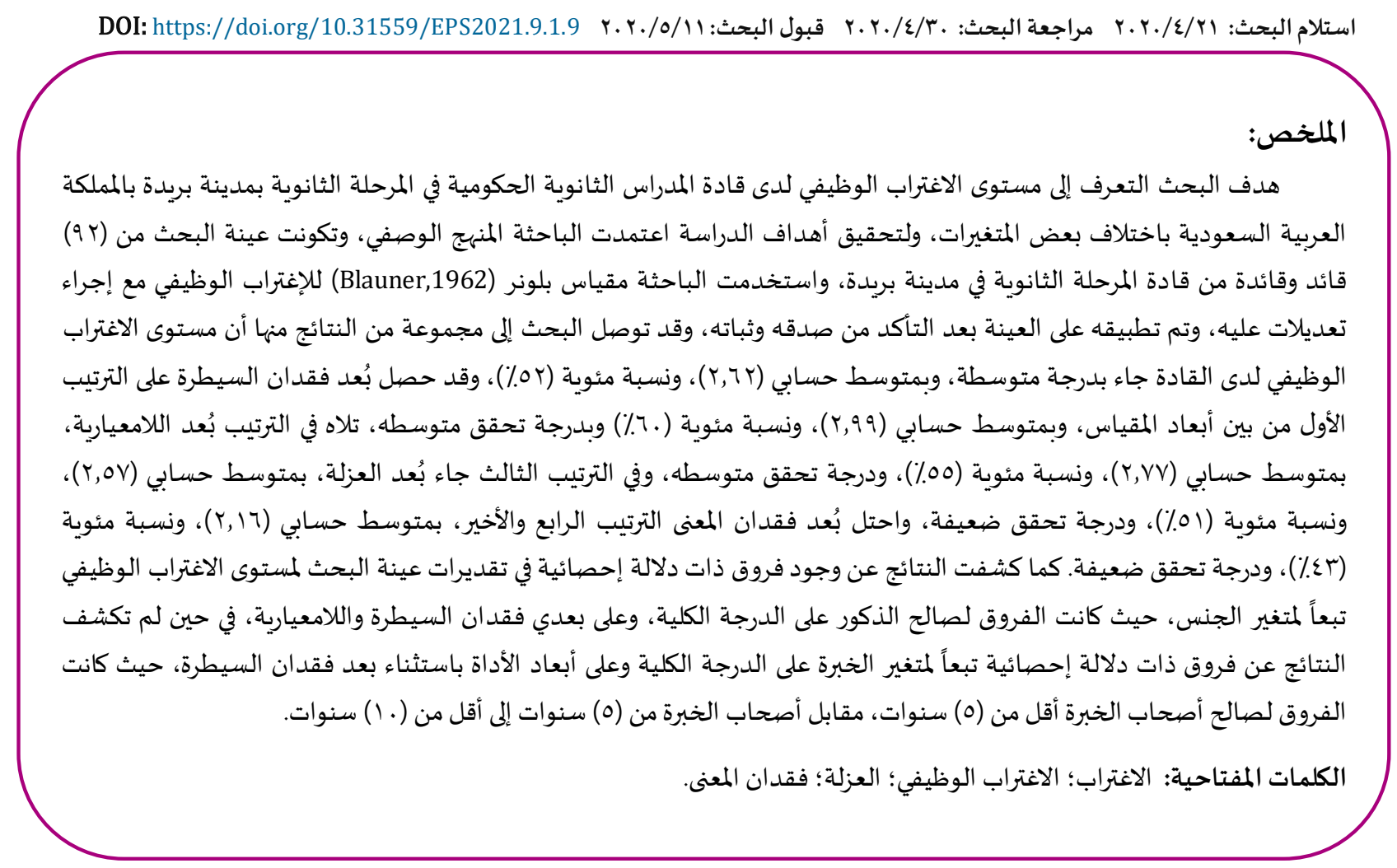

المقدمة:

ازداد اهتمام الباحثين خلال النصف الثاني من القرن العشرين بدراسة الاغتراب كظاهرة انتشرت بين الأفراد في المجتمعات المختلفة، وربما يرجع

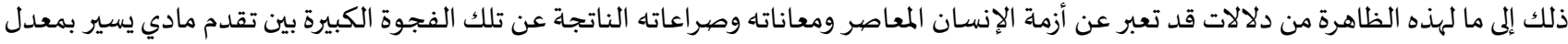

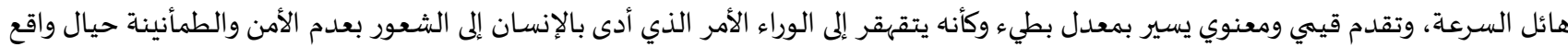

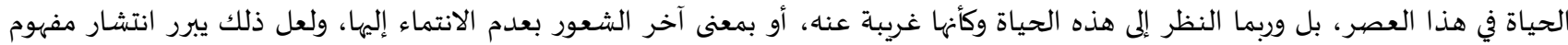

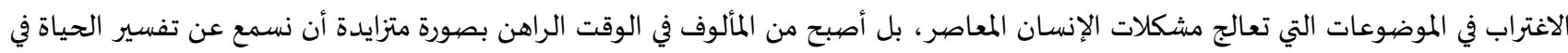


إن الفرد حين يغترب من جميع النواحي نفسياً واجتماعياً وعضوياً، وهو لا يملك سوى ذاته يتمركز عليها ويلتصق بها وأنه يعجز عن استثمار إمكاناته وقدراته ومواهباه ولا يستطيع أن يحقق ذاته، لذلك يمكن اعتبار الاغتراب الوظيفي قضية إنية بالغة الأهمية لكونها أزمة من أزمات الإنسان

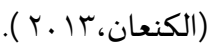

ولقد اهتم علماء النفس والاجتماع بظاهرة الاغتراب رغم حداثها فتعتبر نظرية العقد الاجتماعي المصددر الأساسي لمفهوم الاغتراب في مجال الفلسفة، وفكرتها أن قيام مجتمع مدني يستلزم تنازل بعض الأفراد عن بعض أو كل حقوقهم للمجتمع أو السلطة بحثاً عن الأمن الاجتماعي، ويعتبر هيحل من أوائل المفكرين الذين استخدموا مصطلح الاغتراب على نحو منهجي ومفصل، حيث رأى أنه يوجد انفصال متأصل في وجود الإنسان كفاعل

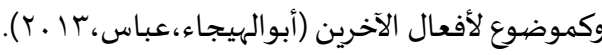

أما كارل ماركس فيتعبر في مقدمة من تناولوا الاغتراب لاعتباره ظاهرة اجتماعية تاريخية سواء الاء من حيث نشأهاءتها أم تطورها، وقد تدرج حتى وصل إلى فكرته الأسـاسية عن الاغتراب وهي اغتراب الإنسان عن العمل من خلال فهماه للنظام الاقتصادي، وتناول ماركس الاغتراب الذي يصاحب العمليات

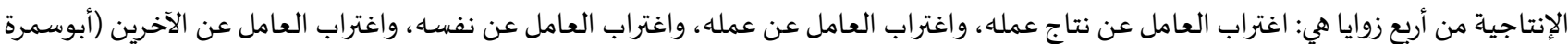

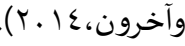

وفي العصر الحديث تناولت العديد من الدراسات ظاهرة الاغتراب الوظيفي حيث يرى (الصرايرة،ه . ب) أن الاغتراب ينشأ بسبب التنظيم وعوامله المختلفة التي من شأها تعريض الأفراد للعديد من العقبات والمواقف التي من قدراتهم وقابليتهم في إشباع ما يطمحون إليه، فيواجهون الفشل

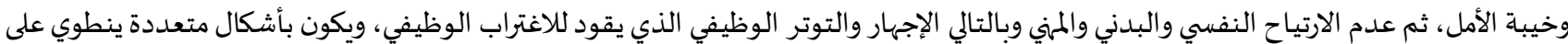
العناصر السلبية والتخريبية مما يجعله من أخطر الظواهر التي تواجه الأفراد في التنظيمات المعاصيرة.

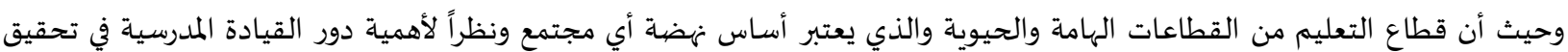
الأهداف التربوية والتعليمية حيث يعتبر القائد الشخصية الأكثر أهمية وتأثيراً في المدرسة فهو الشخص المسؤول عن جميع الأنشطة الحاصلة في المدرسة ومحيطها، فسوف تركز هذه الدراسة على مستوى الاغتراب الوظيفي لدى قادة المدراس.

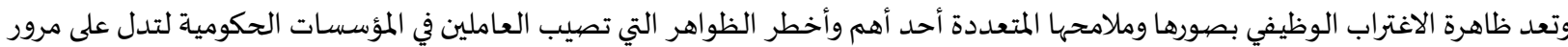
المؤسساة بأزمة حقيقية تهدد نجاحها وتميزها وبالاستناد إلى الدراسات السابقة فقد أكدت دراسة (حوالة وجستينة، 19 ــץ) أن مستوى تحقق أبعاد

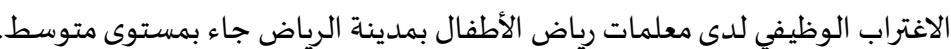

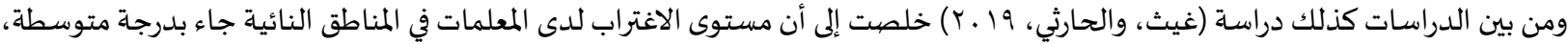

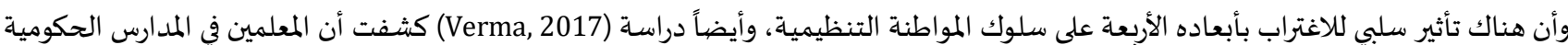
شعروا بالغربة عن العمل أكثر من المعلمات في المدارس الحكومية.

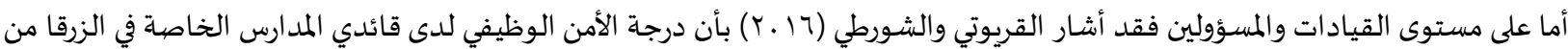

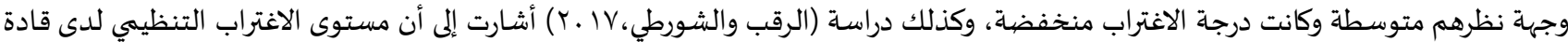

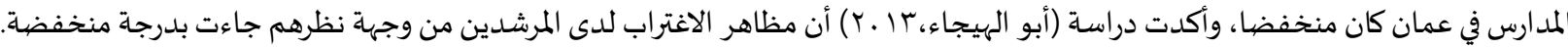

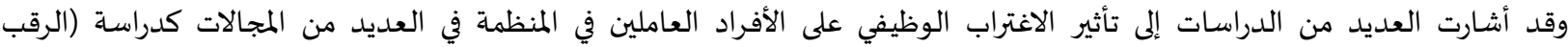

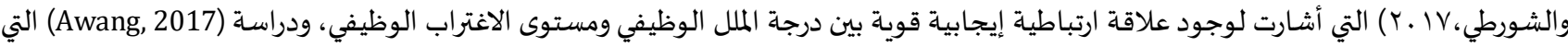
توصلت إلى أن هناك علاقة طردية بين الاغتراب الوظيفي والتوتر المرتبط بالوظيفة. وقد توصلت عدد من الدراسات أنه توجد علاقة عكسية بين الاغتراب وعدد من المتغيرات فقد أظهرت دارسة القريوتي والشورطي (7 إبـ) وجود

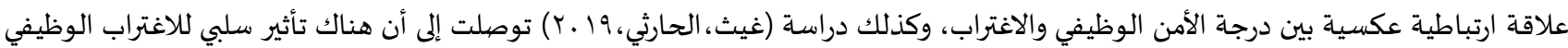

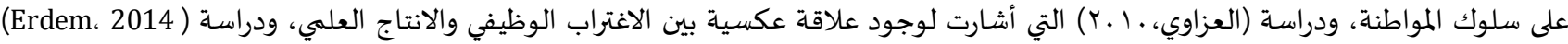

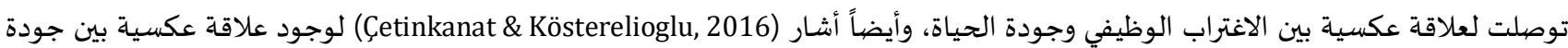
الحياة والاغتراب الوظيفي.

مشكلة البحث:

قد يواجه قادة المدارس العديد من المشاكل الإدارية والتنظيمية نظراً لطبيعة عملهم ووجودهم كحلقة وصل بين المعلمين والإدارة التعليمية، مما

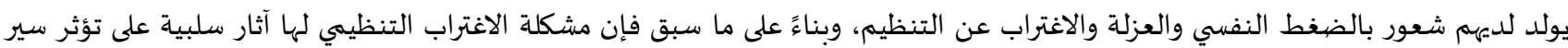

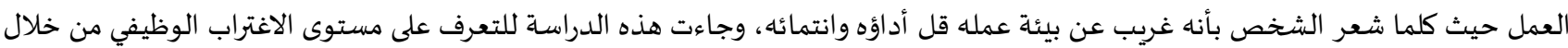

أسئلة الدراسة التالية: 
1. ما مستوى الاغتراب الوظيفي لدى قادة المدارس الثانوية الحكومية في مدينة بريدة؟

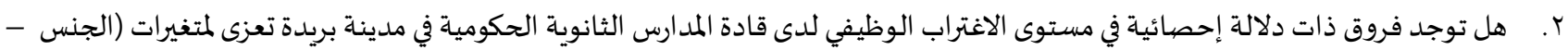

1. التعرف على مستوى الاغتراب الوظيفي لدى قادة المد ارس الثانوية الحكومية في مدينة بريدة.

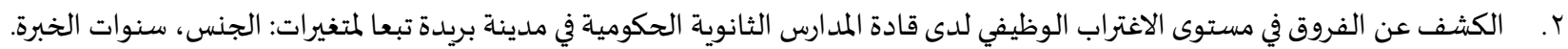
r. تقديم مقترحات تسهم في خفض مستوى الاغتراب الوظيفي لدى قادة المدارس الثانوية الحكومية في مدينة بريدة.

تحددت أهمية الدراسة بما يلي: ا. قد تثري المكتبات العربية بشكل عام والسعودية بشكل خاص وتشكل بد بداية لدراسات وأبحاث أخرى.

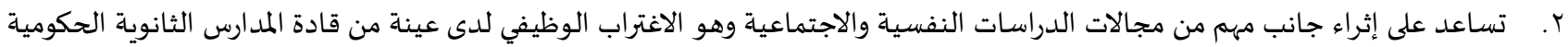
بمدينة بريدة. توجه انتباه المسئولين في وزارة التعليم لوضع خطط وبرامج للحد من الآثار السلبية للاغتراب الوظيفي لدى قادة المدراس من أجل رفع شعورهم بالتفاؤل والذي يساهم بدوره في تعزيز الكفاءة الذاتية لديهيهم. ع. وسبب اختيار الباحثة هذه الدراسة هو أهمية الشعور بالانتماء الوظيفي وتأثيره على العمل في الميدان التعليمي من خلال التعرف على مستوى الاغتراب لدى قادة المدارس لتوضيح المشاكل التنظيمية التي تواجههم وتدارك ما يترتب عليها من نتائج سلبية. حدود البحث: حدود موضوعية: الكشف عن مستوى الاغتراب الوظيفي لدى قادة المدارس (بأبعاده: فقدان السيطرة/فقدان المعنى/فقدان المعايير/الانعزال

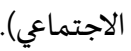
حدود مكانية: تقتصر الدراسـة على المدارس الثانوية الحكومية بمدينة بريدة . حدود بشرية: قائدي وقائدات المدارس الثانوية الحكومية بمدينة بريدة.

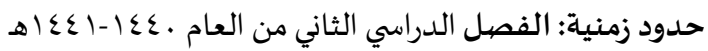
الاغتراب الوظيفي: "شعور الموظف بالغربة في موقع عمله، إذ يفقد الانتماء الوظيفي والتنظيمي بسبب الانغماس في البيروقراطية والشعور بعدم الرضا

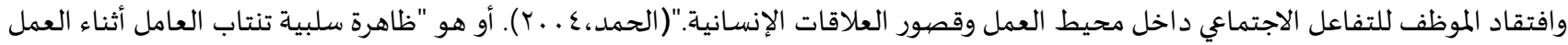

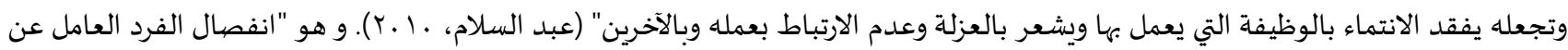

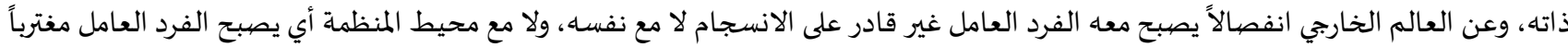

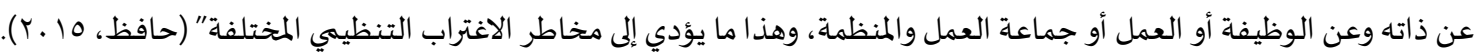

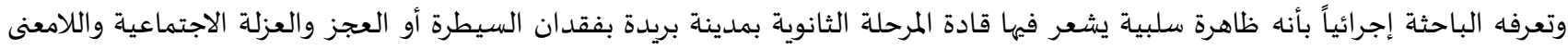

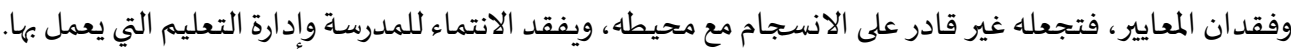

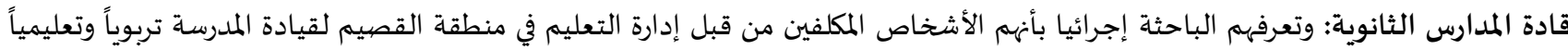
لتحقق الأهداف المنشودة.

الدراسات السـابقة:

قامت الباحثة بالاطالاع على العديد من الدراسـات السابقة والمتعلقة بموضيوع الدراسة الحالية وكان من أهمها ما يلي:

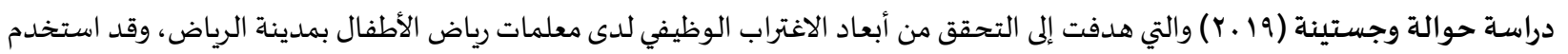
المنهج الوصفي والاستبانة كأداة لجمع البيانات، وتكونت العينة من (ع乏 V) معلمة ممن تم استرجاع الاستبانة منهم، وكشفت الدراسة أن مستوى

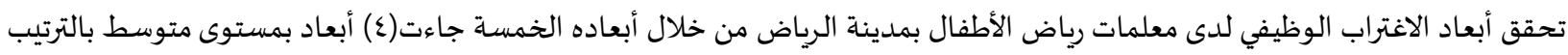


التالي: العجز، فقدان المعنى، التمرد، اللامعيارية وأن مستوى تحقق أبعاد الاغتراب الوظيفي لدى معلمات رياض الأطفال بمدينة الرياض من ألداض خلال أبعاده الخمسة جاءت(ع) أبعاد بمستوى متوسط بالترتيب التالي :العجز، فقدان المعنى، التمرد، اللامعيارية بينما جاء بعد العزلة بمستوى بهـي

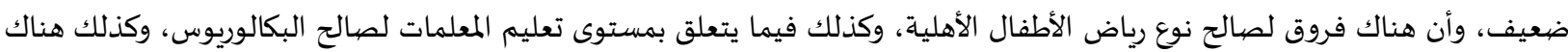

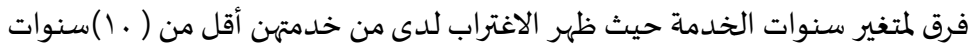

وهدفت دراسة غيث والحارثي (19 ب) لمعرفة أثر الاغتراب الوظيفي بأبعاده (فقدان القوة، والسيطرة، وفقدان المعنى، وفقدان المعايير/

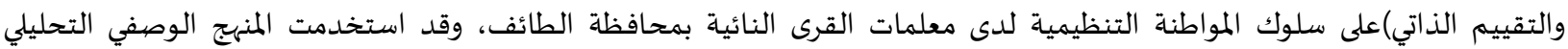
والاستبانة كأداة لجمع البيانات، وتكونت العينة من ( I9Y) معلمة في (rY)مدرسة من مدارس التعليم العام بمراحلها الثلاث وقد أسفرت النتائج

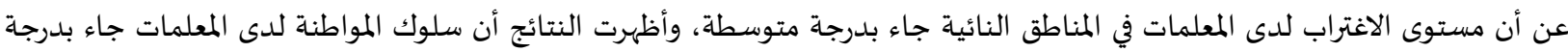

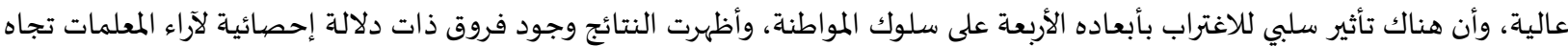
الاغتراب الوظيفي تعزى إلى اختلاف المؤهل العلمي. وتقصت دراسة الرقب والشورطي (Y) (Y) درجة الملل الوظيفي وعلاقتها بمستوى الاغتراب التنظيمي لدى مديري المدارس في عمان، وقد استخدمت منهج وصفي ارتباطي، وأداة البحث تكونت من استبيانين الأولى تقيس درجة الملل الوظيفي والثانية مستوى الاغتراب التنظيمي تكونت

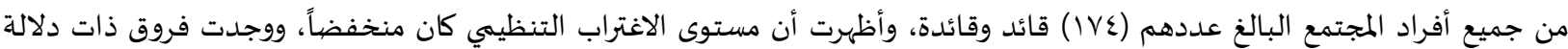

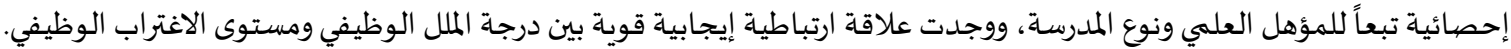
وأوضح أو انج (Awang, 2017) أثر اغتراب العمل في التوتر المرتبط بالوظيفة وعبء العمل الزائد وجهد العمل، وقد استخدم الدراسة المنهج

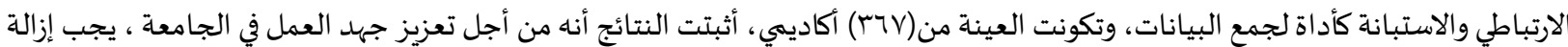
أو تقليل توتر العمل والتوتر المرتبط بالوظيفة وعبء العمل الزائد، إضافة الى اغتراب العمل يؤثر تأثيراً متداخلاً في التوتر المرتبط بالوظيفة

وعلاقات العمل الزائدة والجهـد.

وبيَن فيرما (Verma, 2017) الفارق القائم بين غربة عمل معلمي المدارس الابتدائية في المدارس الخاصة والحكومية وبين غربة عمل المعلمين

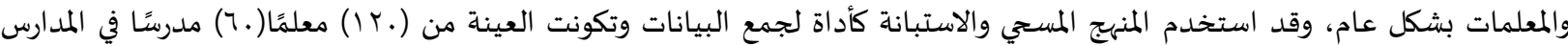

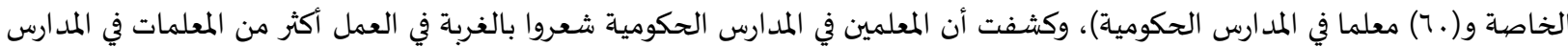

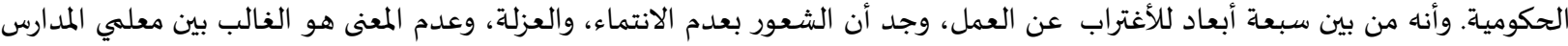
الابتدائية مقارنة بالأبعاد الأخرى. وذكرت دراسة القريوتي والشورطي (17 ـ إلتي هدفت إلى تقصي درجة الأمن الوظيفي وعلاقتها بمستوى الاغتراب الوظيفي لدى مديري

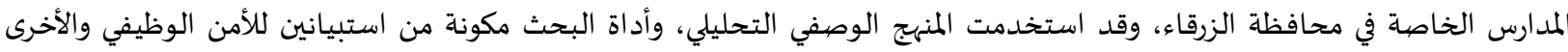

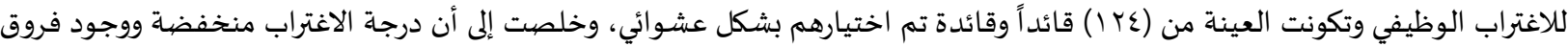

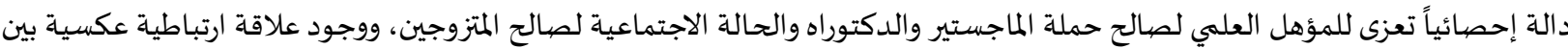
درجة الأمن الوظيفي والاغتراب.

وتناولت دراسة كل من جيتن كنات وكوستريل أوغلو (Çetinkanat \& Kösterelioglu, 2016) العلاقة بين جودة الحياة العملية وغربة العمل

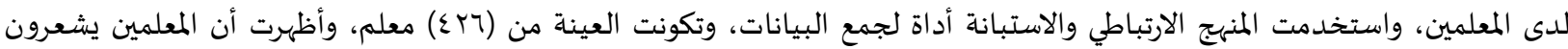
بالغربة في المدرسـة، بالإضافة لاكتشاف علاقات سلبية وهامة بين جميع الأبعاد الفرعية لجودة حياة العمل والأبعاد الفرعية لغربة العمل. وقامت كل من تخة ومزياني (10 • ب) بدراسة هدفت إلى الكشف عن مستوى الاغتراب الوظيفي لدى عمال المديرية الولائية للتجارة بورقلة،

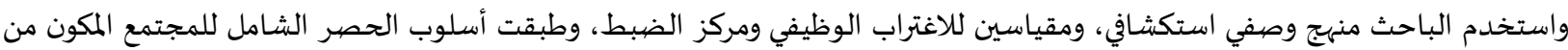

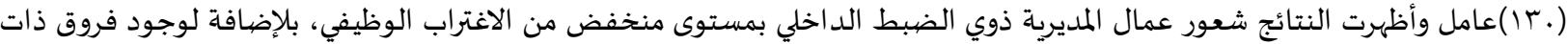
دلالة إحصائية في السن والأقدمية ونوع الوظيفة. وهدفت دراسة إيردم (Erdem, 2014) إلى تحديد مستوى جودة حياة معلمي المدارس الابتدائية (QWL) للتنبؤ بغربة العمل وقد استخدم المنهج الارتباطي ونموذج المسح العلائقي لجمع البيانات، وتكونت العينة من (T\&؟) معلم، وتوصلت إلى وجود علاقة سلبية كبيرة بين أبعاد الاغتراب

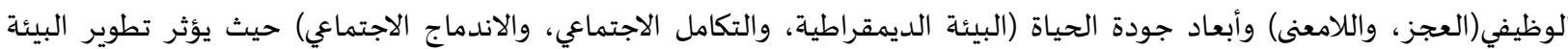
الديمقراطية في المدارس في خفض مستوى الاغتراب الوظيفي بأبعاده(عدم المعنى، والعزلة).

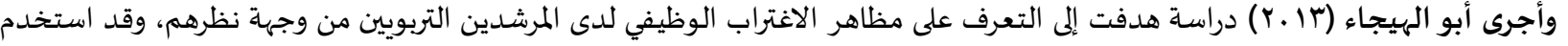

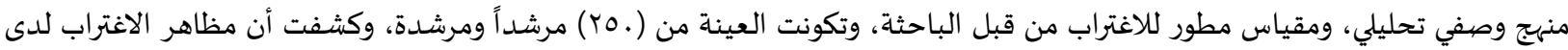


المرشدين من وجهة نظرهم جاءت بدرجة منخفضة وكان أعلاها فقدان المعايير و أقلها مجال فقدان السيطرة، وتوجد فروق في مظاهر الاغتراب الوظيفي تعزى للمؤهل العلمي.

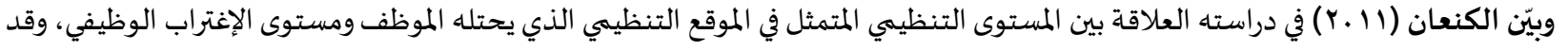

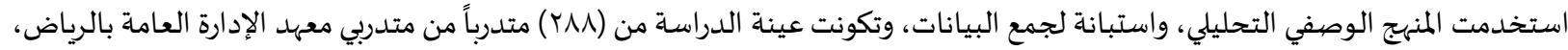
وتوصلت إلى اختلافات في مستوى الاغتراب الوظيفي باختلاف المستوى التنظيمي.

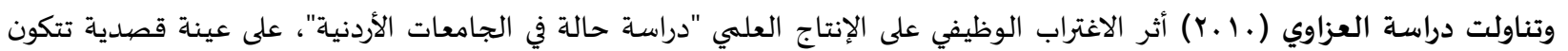

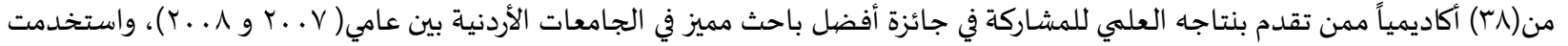
المنهج الوصفي التحليلي واستبانة لقياس المتغيرات لقياس مظاهر الاغتراب والإنتاجية العلمية، وتوصلت إلى وجود علاقة ارتباط سلبية متوسطية

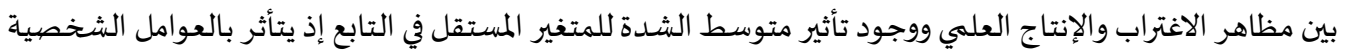

التعليق على الدراسات السابقة:

يتضح من الدارسات السابقة اشتراكها في دراسة مظاهر وأبعاد الاغتراب الوظيفي واختصاصها بالمجتمع التربوي باختلاف مستوياته في غالها كما

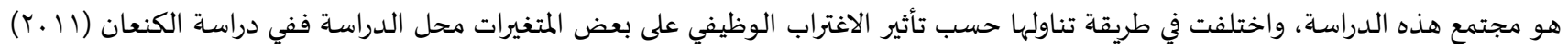

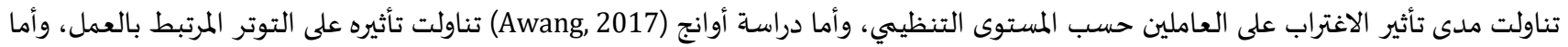

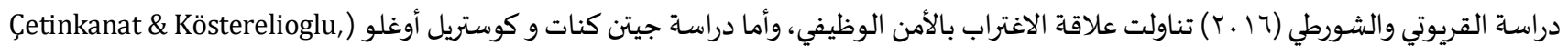

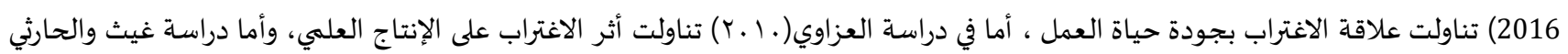

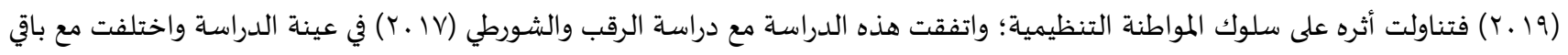

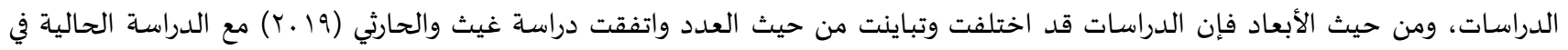
اعتمادها للأبعاد التالية : العجز، وأو فقدان السيطرة، وفقدان المعايير، والعزلة، واللامعنى.

الإطار النظري:

يتناول الإطار النظري مفهوم الاغتراب الوظيفي لدى العديد من الباحثين وأبعاده المتمثلة في العجز، واللامعنى، والعزلة، واللامعيارية، بالإضافة إلى أهم النظريات المتعلقة بالاغتراب الوظيفي والعوامل التي تؤدي لظهور الاغتراب الوظيفي في المنظمة سواء الخاعراصية بها أو بالعامليين بها، وسبل مواجهة الاغتراب الوظيفي. مفهوم الاغتراب:

لقد ازداد اهتمام الباحثين خلال النصف الثاني من القرن العشرين بدراسة الاغتراب كظاهرة انتشرت بين الأفراد في المجتمعات المختلفة، وربما ويرجع ذلك إلى ما لهذه الظاهرة من دلالات قد تعبر أزمة الإنسان المعاصر ومعاناته وصراعاته الناتجة من تلك الفجوة الكبيرة بين تقدم مادي يسير

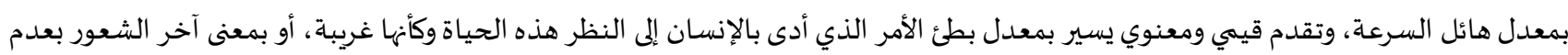

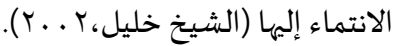

وقد عرف (موسى، Y . . r) الاغتراب الوظيفي هو شعور الفرد بانفصاله عن ذاته وقيمه ومبادئه ومعتقداته وطموحاته وينعكس ذلك من خلال

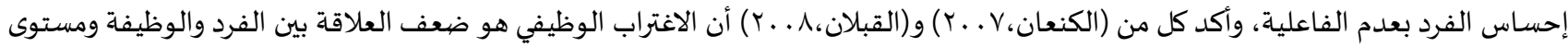
الاندماج الذي قد يكون نفسياً أو فكريًاً أو مهنياً.

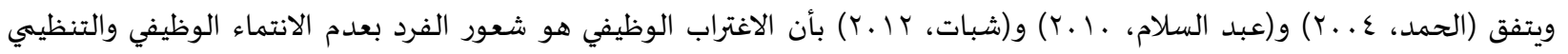

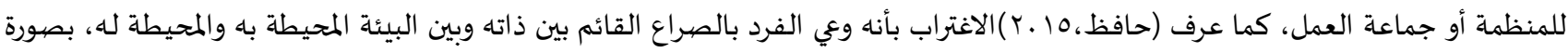

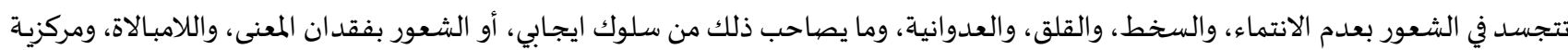

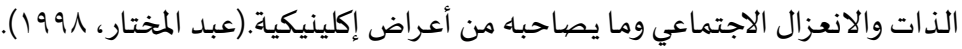
مظاهر الاغتراب الوظيفي (أبعاده): يعتبر (Siman, 1959) من أوائل علماء الاجتماع الذين نقلوا الاغتراب من المفاهيم إلى الأبعاد وهي: العجز أو انعدام القوة، اللامعنى، العزلة

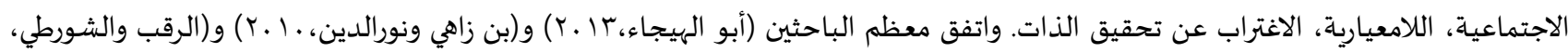

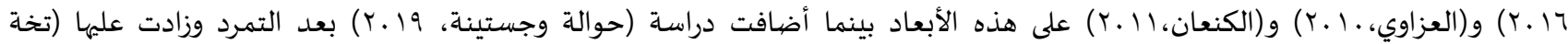

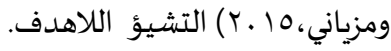


ا. أ. فقدان السيطرة (العجز):

أن العجز يقصد به افتقاد الفرد القدرة على التحكم في المنظمة التي يعمل بها، حيث يتوقع الفرد في هذه الحالة أن سلوكاه لن يأتي بالنتائج

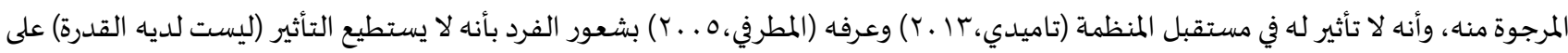

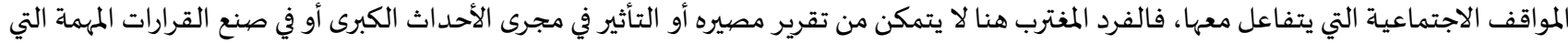
تتناول حياته ومصيره فيعجز بذلك عن تحقيق ذاته.

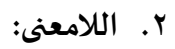

وتعني شعور الفرد بأنه يفتقر إلى مرشد أو موجاه للسلوك، ويشعر الفرد بالفارغ الهائل نتيجة لعدم توافر أهداف أساسية تعطي معنى لحياته وتحدد اتجاهاته وتستقط نشاطاته، وأيضاً عدم قدرة الفرد على فهم ما يدور حوله من فعاليات تنظيمية وعلاقة ما يكلف بالقيام باه من مهام بأهداف المنظمة التي يعمل بها.

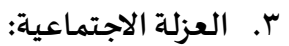

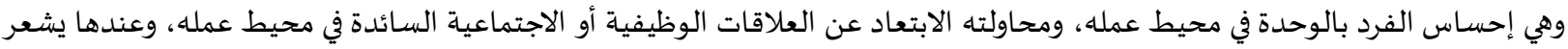

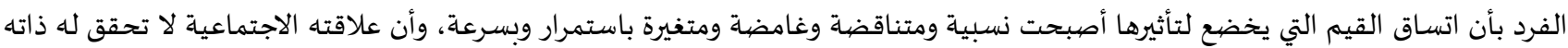
وتتجهاء تبعاً لذلك إلى العزلة والنفور عن الذات الفيرات ع. اللامعيارية: وتعني شعور الفرد بأن الوسائل غير المشروعة مطلوبة، وأنه بحاجة لها لإنجاز الأهداف، وهذه الحالة تنشأ عندما تتفكك القيم والمعايير

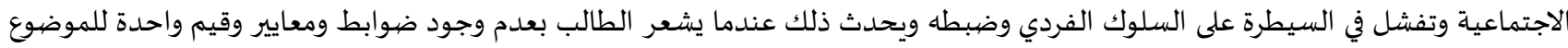
الواحد، فيصطدم بوجود القيم ونقيضها، فتحدث الفجوة بين الغايات والوسائل، فيشعر الفرد بضياع القيا فيم والمعايير.

$$
\text { 1. نظريات الاغتراب الوظيفي: }
$$

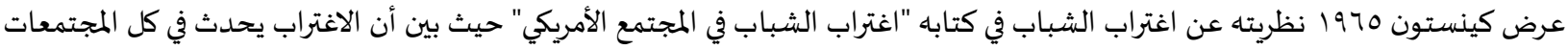

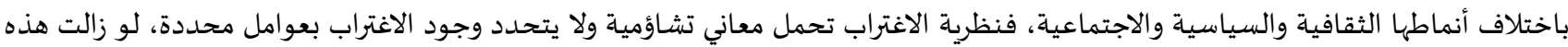
العوامل زال معه الاغتراب (Keniston,1965).

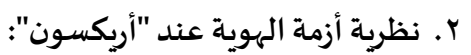

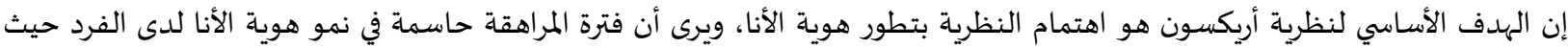

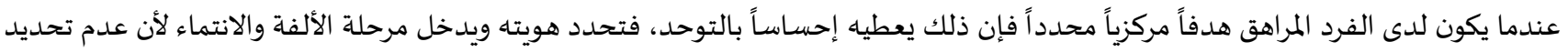
الهوية للمراهق وعدم توحده يؤدي بالفرد إلى الشعور بالاغتراب (Erikson,1968).

$$
\begin{aligned}
& \text { العوامل التي أدت لظهور الاغتراب الوظيفي: } \\
& \text { وتنقسم العوامل المؤدية للاغتراب الوظيفي إلى قسمين: } \\
& \text { ا. ا. عوامل تعود إلى المنظمة. } \\
& \text { r. آ. عوامل تعود إلى العاملين في المنظمة. } \\
& \text { عوامل تعود إلى المنظمة: }
\end{aligned}
$$

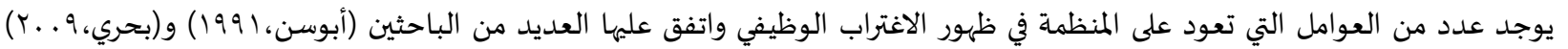

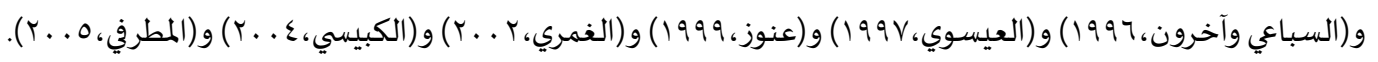

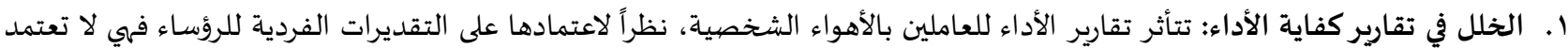
أساس موضوعي وهذا يؤدي إلى خلل في العلاقات الوظيفية بين العاملين والإدارة.

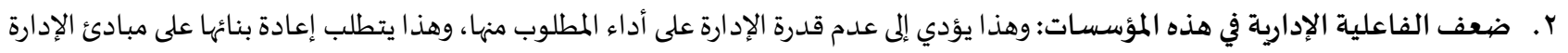
السلوكية، لتتحمل كافة مسؤولياتها وتجاري التطور التقني السريع من خلال السماح لكل موظف بالمشاركة في صنع القرارات التي تؤثر به وتتعلق

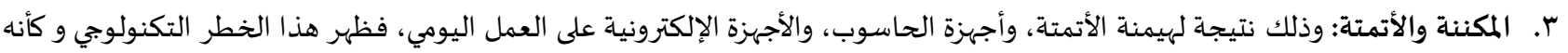

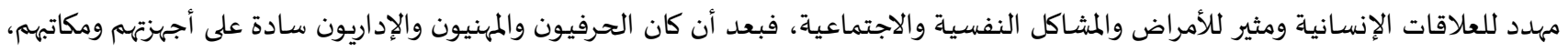
أصبحوا خدما لها خاضعين لإرادها. 
ع. اتساع حجم المنظمة: من الآثار السلبية على العاملين ازدياد حجم المؤسسة فهو يؤدي إلى تشتت جهود الرؤساء، فيشعر العاملين أن الاشراف

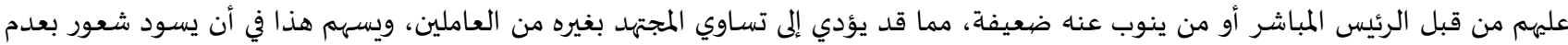

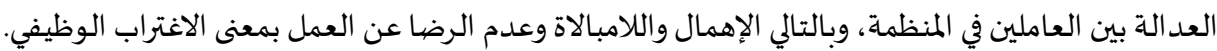
0. ضعف نظام الحو افز: يعتبر من أهم العوامل المؤدية للاغتراب الوظيفي عدم وضوح نظام الحوافز أو خضوعاه للمجاملات والعلاقات

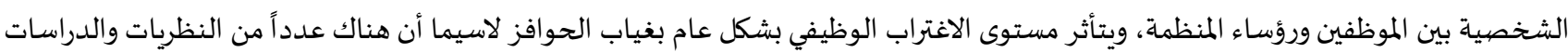
التي سعت إلى معرفة العلاقات بين الاغتراب الوظيفي والحوافز، فترى مثلا مدرسة العلاقات الإنسانية أن الموظف السعيد هو هو موظف منتج، وعموماً

قد لا يكون الاغتراب ناتج من العمل بذاته بل قد يكون ناتج عن الظروف المحيطة بالعمل والزملاء وبيئة العمل ونوعياة الخدمات.

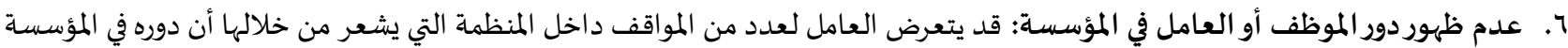

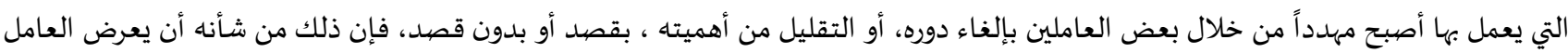

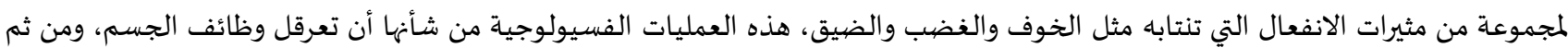

تسـاعد على الشعور بالاغتراب العامل.

V. الاحتفاظ بالمعلومات: إن من أخطر الآثار السلبية في مواقع العمل الاحتفاظ بالمعلومات والخبرات وعدم نقلهاتها للعاملين والصفف الثاني من القيادات، وكذلك وجود القيادات والمشرفين والعاملين وأصحاب الخبرات الطويلة في العمل ممن يحتفظون بمعلوماتهم ولا يقومون بدورهم التدريبي لمن

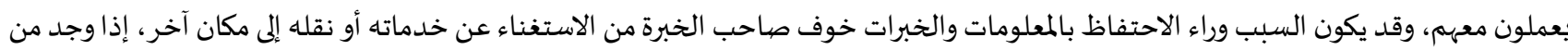
يقوم بعمله، وقد أثبتت جميع التجارب الميدانية، أن كل النظم والقوانين والفلسفات لم تنجح في علاج هذه المشكلة وتغيير هذا السلوك.

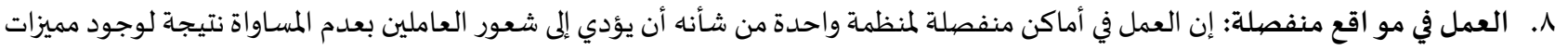
لبعض المواقع لا تتوفر للبعض مثل الحوافز والبدلات و أوقات وساعات العمل، وكذلك وجود بعض الجوانب العبل السلبية في الأماكن التي تبعد عن الإدارة

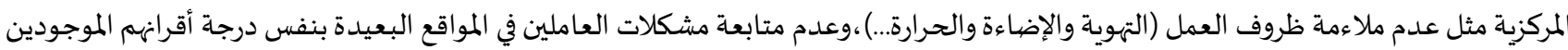
في الموقع الرئيسي أو الفروع القريبة منها. ملاعهد.

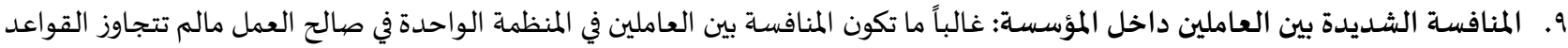

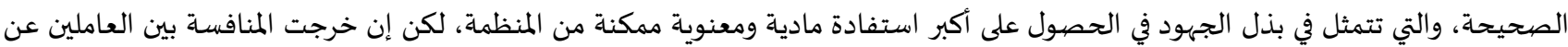
هذه القواعد كأن يتبع العاملون بعض الأسـاليب غير المشروعة للوصول إلى مكاسب لا يستحقونها، فإن ذلك من شأنه أن يدفع العاملين الشرفاء إلى إلى اليأس من الوصول للمكاسب التي يريدونها، ومن ثم تنخفض معدلات أدائهم فيستسلمون لليأس ومشاعر الإحباط من شأنه أن يؤدي إلى اغترابهم وظيفيا عن الوزارة أو المؤسسة التي يعملون بها.

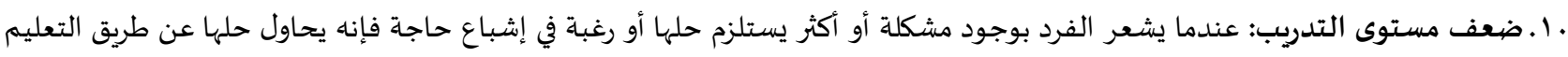
والتدربب من أجل رفع كفاءته في العمل والتفكير والانجاز وبث روح التقدم، من أجل ذلك أصبح التعليم والتدريب جزءاً من العملية الإنتاجية في المجتمع المعاصر لتحقيق التطور والتقدم. عوامل تعود إلى العاملين في المنظمة:

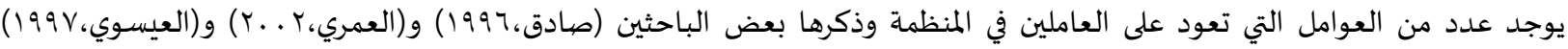

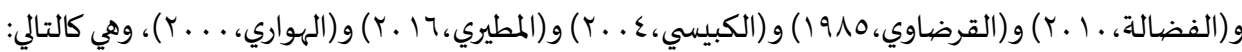

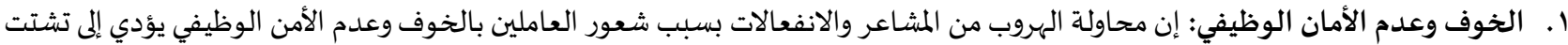

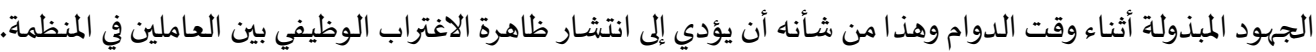

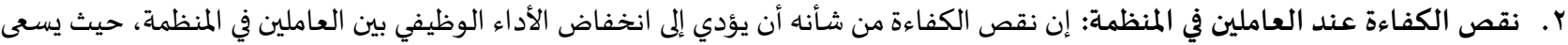

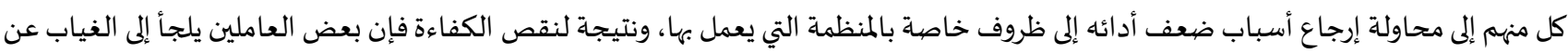
العمل، كما يتصرف البعض منهم قبل نهاية الدوام، وأيضيا تكثر المشاجرات بين العاملين، وهذا يمثل الاغتراب الوظيفي.

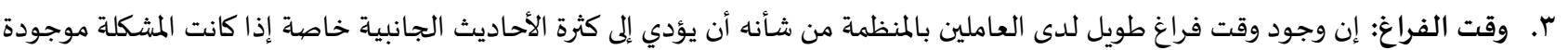
لدى عدد كبير من العاملين، حيث ينصرف العاملين إلى بحث مشاكلهم الشخصية والتشاور في حلها بدلاً من قضاء وقت الدوام الرسمي في إنجاز الأعمال.

توجهات العاملين في المنظمة: إن عدم ملاءمة قيم وضوابط وأهداف العمل للفرد، أو الهدف الذي يتجهاء عمل الفرد نحوه غير مرغوب فيه، أو أن

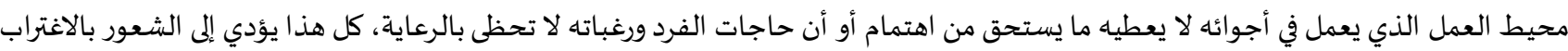
الوظيفي. 
ع. سوء إدارة الوقت: إن أكثر العاملين لا يحسنون استغلال الوقت بفعالية وللأسف هناك من الناس من يظن أن تنظيم الوقت معناه الجد التام، و لا وقت للراحة، والبعض الآخر يظن أن تنظيم الوقت شيء تافه لا وزن له، ذلك لأهم لا يقيمون للوقت وزناً ولا أهمية، وهذه المفاهيم تجعل عملنا

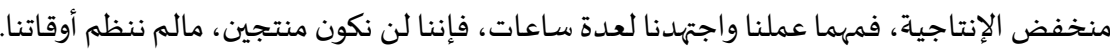
ه. ضعف مقومات القيادة: إن ضعف مقومات القيادة لدى القائد وعد إلمامه بالمهارات تعتبر من أهم العوامل المؤدية للاغتراب الوظيفي، لذا لذا فقد حرص الدين الإسلامي على توضيح المقومات الأساسية في القائد الإداري ليكون أهلاً للقيادة الرشيدة. 7 إعدم التخصص بالعمل من قبل العاملين: إن تنمية الموارد البشرية تتم عن طريق التوسع في التعليم والتدريب، ومن ثم يتوفر عدد من المتخصصين في مجالات العمل المختلفة، وتكمن المشكلة في عدم الاستخدام الأمثل لهذه التخصصيات، وذلك بوضيعها في مجالات عمل مختلفة تمامدا عن فئن

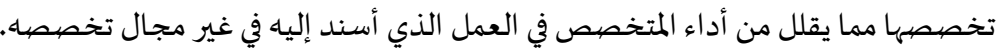
V V. اليأس والاستسلام للفشل: إن اليأس من أسوء الصفاء المات التي انتشرت بين العاملين، إن عدم الاعتماد على النفس، والثقة والمقدرة على العمل،

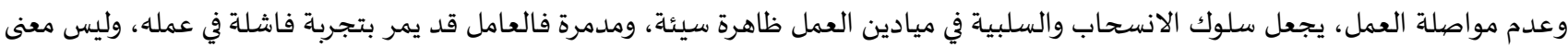

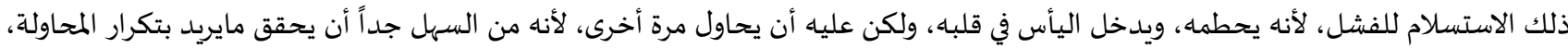

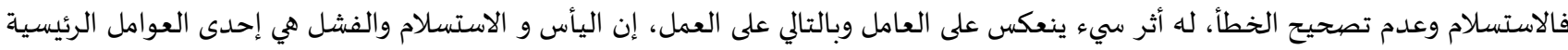
لظاهرة الاغتراب الوظيفي. ^. الكبت واللاوعي: إن الأعراض النفسية، والفيزيولوجية للكبت، واللاوعي، تتمثل في القلق والتوقع السيء، والتحفز دون أن يكون هناك سبب لذلك، مع سهولة الاستثارة العصبية، وعدم الاستقرار الحركي والأرق، ومن الملاحظ على العامل الذي يعاني من الكبت، عدم قدرته على أداء العمل

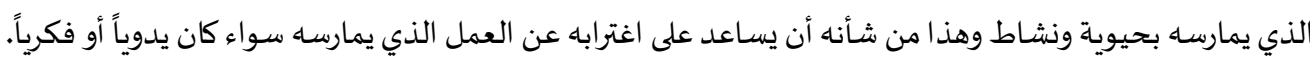

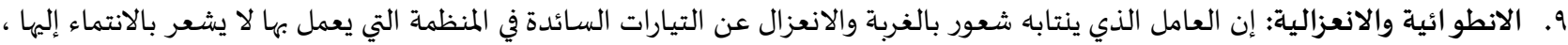

وهذا النوع من العاملين يعاني من الاغتراب النفسي الذي يؤثر على سلوكه داخل المنظمة (الزغل وآخرون، ـ ـ99 19 ).

سبل مواجهة الاغتراب الوظيفي:

ذكر الطهطاوي العديد من الآثار السلبية لشعور الفرد بالاغتراب في مجال العمل حيث يفقد الانسجام والتأقلم، ويزيد شعور الفرد بالوحدة

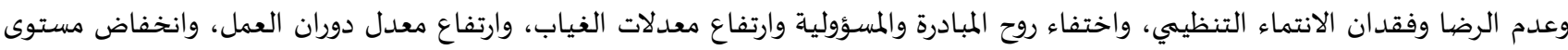

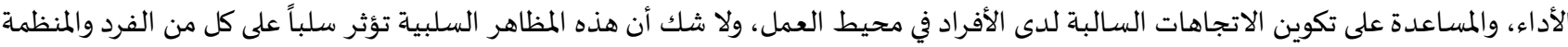

(المطيري، (r)

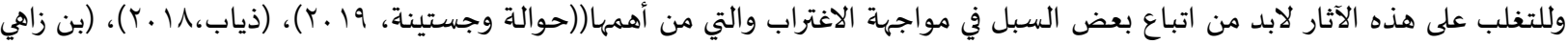

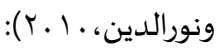

ا- الوعي بالاغتراب والقدرة على تحمل العزلة: يعرف (فرومان) الوعي بعملية الإيقاظ ورؤية ما يكون أمام الإنسان، فالوعي يعني طرح الأوهام، ولكي

ينمو لابد أن تختفي التناقضات الاجتماعية وكل النزاعات اللاعقلية التي فرضت على العالى الإنسان عبر تاريخها.

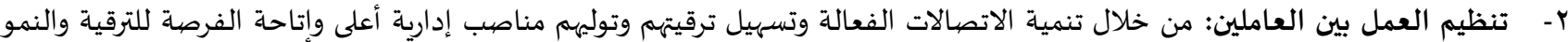

الوظيفي وتغذية احتياجاتهم التدريبية وتوفير روح التعاون وبناء علاقات اجتماعية إيجابية في المنظمة. ب- الموضوعية والشفافية: لابد من الالتزام بالموضيوعية والشفافية في إعداد التقارير وتقييم الأداء ووضوح الأهداف للعاملين، وذلك بالتركيز على برامج التنمية الإدارية لتنمية الاتصالات الفعالة في جميع الجهات.

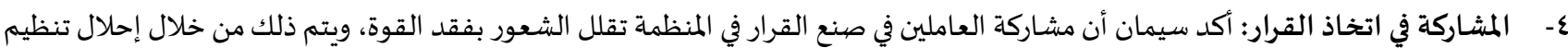
جديد من خلال مساهمة العاملين في تكوينه وإبعاد التنظيم البيروقراطي والتسلط الذي يؤدي في غالب الأحيان إلى ضعف المدان العمل وظهور روح اللامبالاة من قبل العاملين. ه- تحسين بيئة العمل: إن إحداث بعض التغييرات في بيئة العمل من حين لآخر يجعل العامل لا يمل من بيئة العمل وذلك عن طريق توفير فترات للراحة وتحسين وتكييف الجو والتخفيف من حدة الظروف السيئة. 7- المسـاعدة المالية: إن تقديم بعض وتجين القروض للعاملين من أجل حل المشاكل الأسرية ومسـاعدتهم على حل مختلف المشاكل وهذا لإعادة الاعتبار

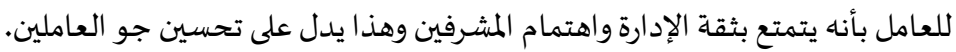

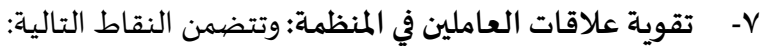


• تقوية علاقة العاملين بالمؤسسة: وذلك من خلال إنشاء وحدة للبحوث النفسية والاجتماعية والتي من أهدافها دراسة مشكلات العاملين والوقوف على المصادر الخاصية بها، ودراسة المتغيرات يمكن أن يساعد على وضع الحلول الوقائية والعلاجية لمشكلات العاملين والعمل على تقوية مناءية عوامل الرضا والإرضاء لديهم. • خلق الانسجام بين العامل وعمله، ويتم ذلك من خلال عدة اعتبارات منها أن تكون العلاقة بين الرئيس والمرؤوس قائمة على الاحترام المتبادل وأن يكون قوامها الود والدفء وأن يكون للعاملين حضور وتمثيل قوي في مجلس الإدارة والنقابة حتى يشعرون بذواتهم وبقوى انتمائهم للعمل. • تقوية علاقة بزملائه، وتعتمد علاقة العامل على اعتبارين رئيسين هما التعاون والمنافسة فضلا عن إثراء الحياة الاجتماعية داخل المؤسسة

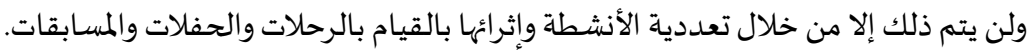

$$
\text { منهجية البحث وإجراءاته: منهج البحث: }
$$

في البحث الحالي تم استخدام المنهج الوصفي المستي الذي ينسجم مع طبيعة الدراسة وأهدافها يتميز المنهج الوصفي المستي بالعديد من المميزات و التي جعلت منه المنهج المعتمد لدراسة الكثير من الظواهر، وخاصة الظواهر و المشكلات ذات الطابع الإنساني والاجتماعي والسلوكي، وجعلت العديد

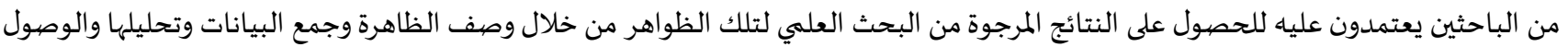

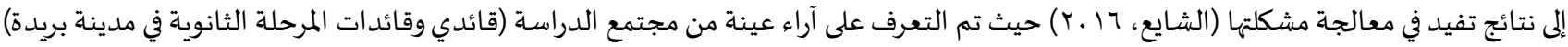

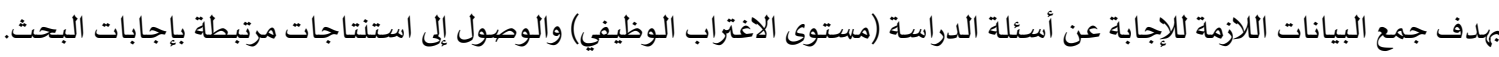
ثانياً: مجتمع البحث:

تمثل مجتمع البحث في جميع قادة المدارس الثانوية الحكومية في مدينة بريدة بمنطقة القصيم بالمملكة العبية السعودية والبالغ عددهم (ب (9)

$$
\begin{aligned}
& \text { قائداً وقائدة، في الفصل الدراسي الثاني من العام الدراسي إعـأهـ }
\end{aligned}
$$

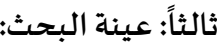

تكونت عينة البحث من (r 9) قائداً وقائدة من قادة المدارس الثانوية الحكومية بمدينة بريدة بمنطقة القصيم بالمملكة العربية السعودية، وهم يمثلون مجتمع الدراسة، وتم التطبيق علههم في الفصل الدراسي الثاني من العام الدراسي اعـأه، والجدول التالي يوضح توزيع أفراد عينة البحث في

\begin{tabular}{|c|c|c|}
\hline 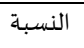 & العدد & 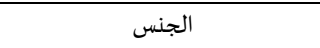 \\
\hline$\%$ & or & ذكر \\
\hline$\% \varepsilon r, 0$ & $\varepsilon$. & أنثى \\
\hline النسبة & العدد & سنوات الخبرة \\
\hline$\% 11,0$ & IV & أقل من ه سنوات \\
\hline$\%$ \% , 1 & $T \varepsilon$ & من ه سنوات إلى أقل من · ا سنوات \\
\hline$\% 00, \varepsilon$ & 01 & من ـ ا سنوات فأكثر \\
\hline
\end{tabular}
ضوء المتغيرات المختلفة.

جدول (1): توزيع أفراد عينة البحث الأساسية في ضوء المتغيرات المختلفة

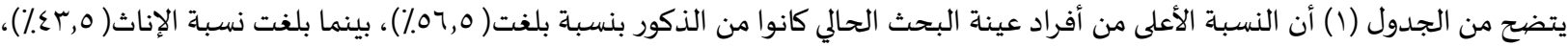

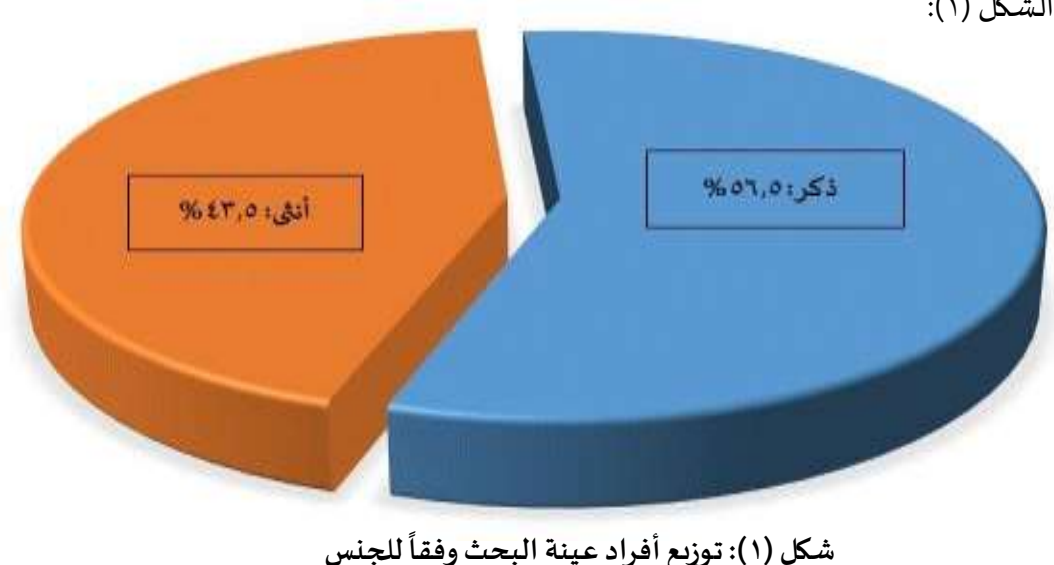

وهو ما يمكن توضيحها من خلال الشكل (1): 
كما يتضح من الجدول (1) أن النسبة الأكبر من أفراد عينة البحث الأساسية كانوا من أصحاب سنوات الخبرة من(· (1) سنوات فأكثر بنسبة

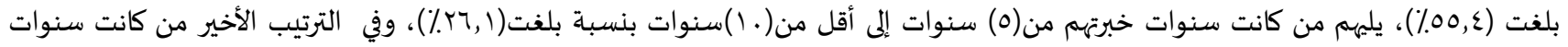

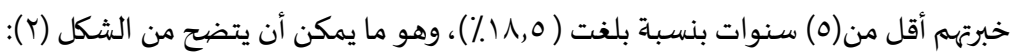

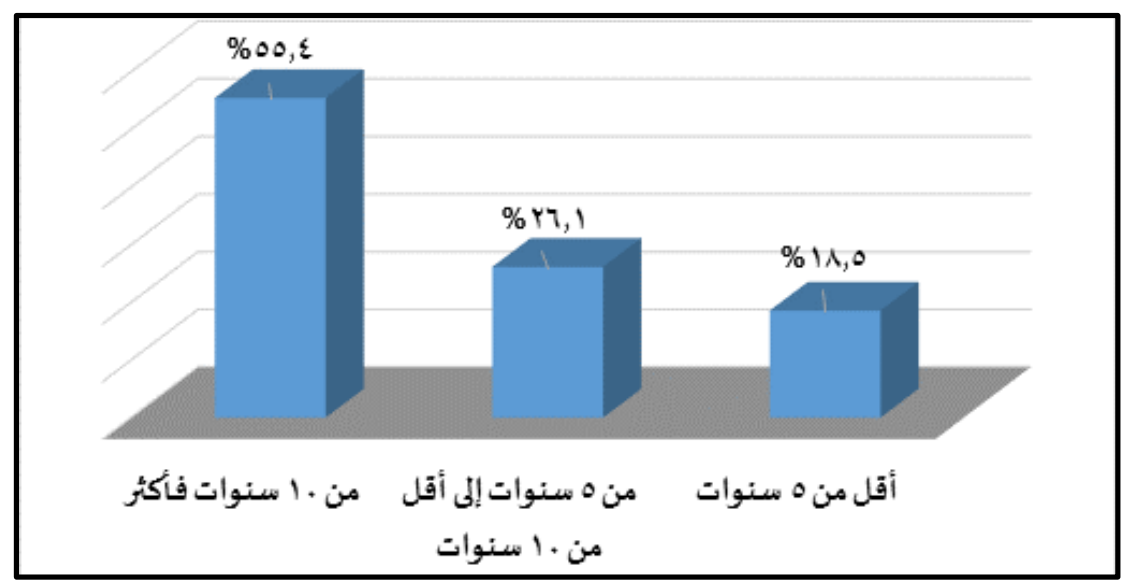

شكل (r): توزيع أفراد عينة البحث وفقاً لسنوات الخبرة

رابعاً: أدوات البحث:

لجممع البيانات اللازمة للإجابة عن أسئلة البحث الحالي وتحقيقه للأهداف التي يسعى إليها، تم استخدام الاستبانة كأداة لجمع البيانات اللازمة من

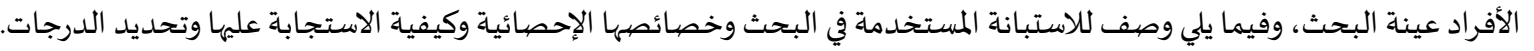

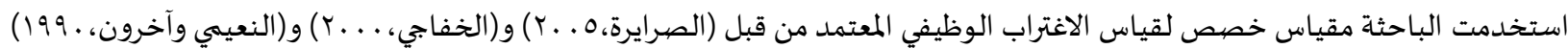

والمأخوذ من(Blauner,1962) وقد تألف من (ع) أبعاد بواقع (1/) بنداً موزعـة كالآتي:

$$
\begin{aligned}
& \text { • البعد الأول: فقدان السيطرة(القوة) بـ (ع) أسئلة. } \\
& \text { • البعد الثاني: فقدان المعنى بـ (ع) أسئلة. } \\
& \text { • البعد الثالث: العزلة الإجتماعية بـ (0) أسئلة. } \\
& \text { • البعد الرابع: اللامعيارية بـ (0) أسئلة. }
\end{aligned}
$$

صيدق وثبات الأداة: أ. أ. صديدق الأداة:

للتحقق من صدق الاستبانة الحالية تم الاعتماد على الصددق الظاهري (صدق المحكمين) Face Validity حيث تم عرض الاستبانة على عدد من المحكمين الخبراء والمتخصصيين في مجال الإدارة التربوية وعلم النفس وطلب منهم دراسة الاستبانة وإبداء آرائهم فيها من حيث مدى ارتباط كل عبارة من

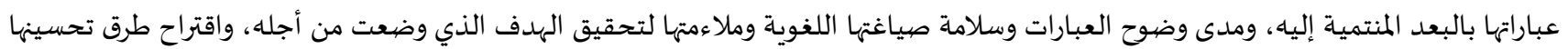
وذلك بالحذف أو الإضافة أو إعادة الصياغة، وقد قدم المحكمون ملاحظات قيمة أفادت البحث، وآثرت الاستبانة، وساعدت على إخراجها بصهورة

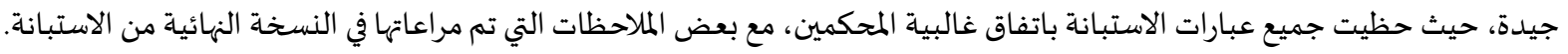
تم كذلك التحقق من صدق الاستبانة عن طريق صدق الاتساق الداخلي Internal Consistency وذلك باستخدام معامل ارتباط بيرسون في مئديات

\begin{tabular}{|c|c|c|c|c|c|c|c|}
\hline الارتباط & العبارة & الارتباط & العبارة & الارتباط & العبارة & الارتباط & العبارة \\
\hline \multicolumn{2}{|c|}{ الللامعيارية } & \multicolumn{2}{|c|}{ العزلة } & \multicolumn{2}{|c|}{ فقدان المعنى } & \multicolumn{2}{|c|}{ فقدان السيطرة } \\
\hline${ }^{* *} ., 0 \leqslant r$ & 1 & 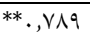 & 1 & ${ }^{* *} ., \mathrm{VVr}$ & $T$ & **., 7ץ & 1 \\
\hline${ }^{* *} \cdot, \wedge$ М & $r$ & $*_{*}^{*}$, or $\varepsilon$ & $r$ & **.,VAY & $r$ & ${ }^{* *} ., \varepsilon \uparrow V$ & $r$ \\
\hline$*^{* *} ., \wedge \vee$. & $r$ & ${ }^{* *} ., \mathrm{V} \vee 0$ & $r$ & **.,VIY & $r$ & **., orq & $r$ \\
\hline${ }^{* *} \cdot, \lambda r_{0}$ & $\varepsilon$ & **.,ATY & $\varepsilon$ & $*^{* *},, 0 \wedge \Lambda$ & $\varepsilon$ & **., Vq. & $\varepsilon$ \\
\hline$*^{* *}$, VII & 0 & **.,T\&. & 0 & & ثق ق & ل مالة عند & \\
\hline
\end{tabular}
حساب معاملات الارتباط بين درجة كل عبارة ودرجة البعد المنتمية إليه العبارة وذلك للتأكد من مدى تماسك وتجانس عبارات كل بعد فيما بينها،

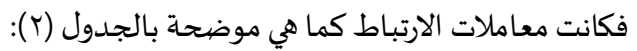

جدول (Y): معاملات الارتباط بين درجات عبارات الاستبانة والدرجة الكلية للبعد المنتمية إليه العبارة 
يتضح من الجدول (r) أن معاملات الارتباط بين درجات بنود الاستبانة والدرجة الكلية للبعد المنتمية إليها البعد، جميعها معاملات ارتباط موجبة ودالة إحصائياً عند مستوى ثقة ا . . . وهو ما يؤكد اتساق وتجانس عبارات كل بعد فيما بينها وتماسكها مع بعضها البعض.

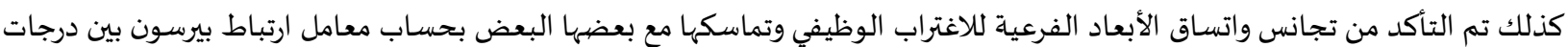

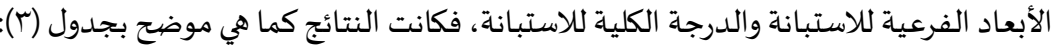

جدول (r): معاملات الارتباط بين درجات الأبعاد الفرعية للاغتراب الوظيفي والدرجة الكلية

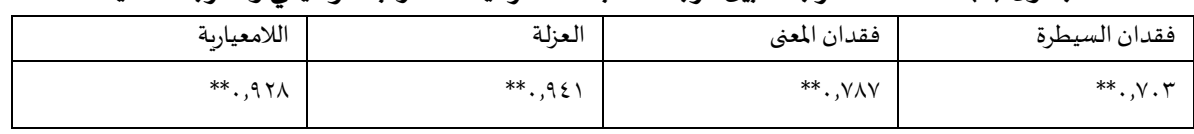

يتضح من الجدول (r) أن معاملات الارتباط بين درجات الأبعاد الفرعية للاستبانة والدرجة الكلية للاستبانة جميعها معاملات ارتباط موجبة ودالة إحصائياً عند مستوى ثقة ا . . . وهو ما يؤكد اتساق وتجانس الأبعاد الفرعية للاغتراب الوظيفي فيما بينها وتماسكها مع بعضها البعض.

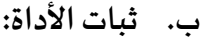

للتحقق من ثبات الأداة وأبعادها تم تطبيقها على عينة استطلاعية من القادة والقائدات التربويات، وتم حساب نسبة الثبات باستخدام معامل

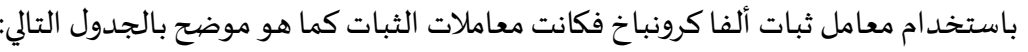

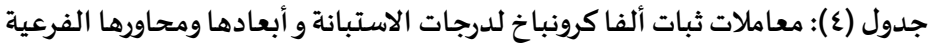

\begin{tabular}{|c|c|c|c|c|}
\hline الاستبانة ككل & اللامعيارية & العزلة & فقدان المعنى & فقدان السيطرة \\
\hline .,人० & Yרו,. & .,VYA &., 9.7 &., 911 \\
\hline
\end{tabular}

يتضح من الجدول (ع) أن لدرجات الاستبانة وأبعادها الفرعية معاملات ثبات مرتفعة ومقبولة إحصائياً؛ ومما سبق يتضح أن للاستبانة مؤشرات إحصائية جيدة (الصدق، الثبات) ويتأكد من ذلك صلاحية استخدامها في البحث الحالي في الكشف عن مستوى الاغتراب الوظيفي لدى قادة المدارس الثانوية الحكومية في مدينة بريدة. ويجب ملاحظة أنه تتم الاستجابة لعبارات الاستبانة المستخدمة في البحث الحالي بأن يتم الاختيار ما بين خمسة اختيارات، تتمثل في (موافق بشـة، موافق، محايد، غير موافق، غير موافق بشدة)، وتقابل الاستجابات الدرجات (0، ع، ؟، ؟، 1) على الترتيب مع مراعاة العبارات السلبية

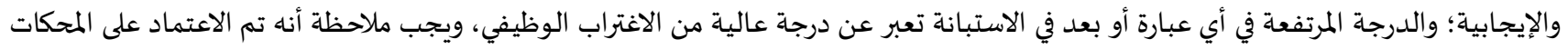
التالية في الحكم على مستوى الاغتراب الوظيفي لدى قادة المدارس الثانوية الحكومية في مدينة بريدة، بناءً على المتوسطات الحسابية للعبارات

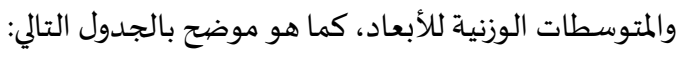

جدول (0): محكات الحكم على مستوى الاغتراب الوظيفي لدى قادة المدارس الثانوية الحكومية في مدينة بريدة

\begin{tabular}{|c|c|}
\hline درجة التحقق & المتوسط الحسابي للعبارة أو المتوسط الوزني للبعد \\
\hline منعدمة & أقل من ^, ا \\
\hline ضعيفة & 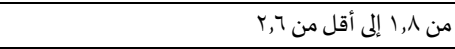 \\
\hline متوسطة & 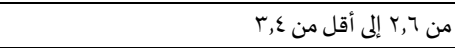 \\
\hline 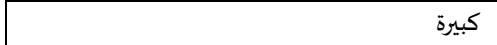 & من ع, إلى أقل من ؟, \\
\hline كبيرة جداً & من Y,ع فأكثر \\
\hline
\end{tabular}

خامساً: الأساليب الإحصيائية المستخدمة:

في البحث الحالي تم استخدام العديد من الأسـاليب الإحصائية باستخدام الحزمة الاحصائية في العلوم الاجتماعية SPSS كالتالي: للإجابة عن أسئلة البحث تم استخدام العديد من الاختبارات مثل (التكرارات Frequencies والنسب المئوية Percent والمتوسطات والانحرافات المعيارية Std. Deviation في الكشف عن مستوى الاغتراب الوظيفي لدى قادة المدارس الثانوية الحكومية في مدينة بريدة، و اختبار "ت"

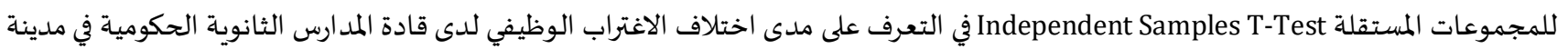
بريدة والتي ترجع لاختلاف متغير الجنس، وتحليل التباين أحادي الاتجاه One Way ANOVA في التعرف على مدى اختلاف مستوى الاغتراب الوظيفي

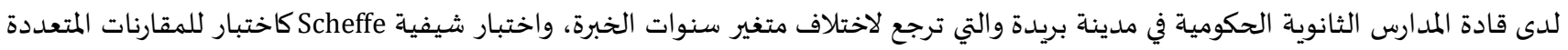
البعدية بين المجموعات في حالة دلالة تحليل التباين أحادي الاتجاه. 
نتائج البحث ومناقشتها:

أولاً: نتائج إجابة السؤال الأول: ينص السؤال الأول للبحث الحالي على "ما مستوى الاغتراب الوظيفي لدى قادة المادئ المدارس الثانوية الحكومية في مدينة بريدة ؟" للإجابة عن هذا السؤال تم حساب التكرارات والنسب المئوية لاستجابات أفراد عينة البحث على كل بند من البنود الاستبانة والمتعلقة مستوى الاغتراب الوظيفي لدى قادة المدارس الثانوية الحكومية في مدينة بريدة، ثم تم حساب المتوسطات والانحرافات المعيارية لهذه الاستجابات وذلك لتحديد درجة تحقق كل عبارة من هذه العبارات، فكانت النتائج كما هي موضحة في التالي: ا. البعد الأول: فقدان السيطرة:

جدول (7): التكرارات والنسب المئوية والمتوسطات والانحر افات المعيارية لاستجابات عينة البحث على بعد فقدان السيطرة

\begin{tabular}{|c|c|c|c|c|c|c|c|c|c|c|c|c|c|c|c|}
\hline \multirow[t]{3}{*}{ الترتيب } & \multirow{3}{*}{ التحقق درجة } & \multirow{3}{*}{ المعياري } & \multirow{3}{*}{ الحستوسطي } & \multicolumn{10}{|c|}{ الاستجابة } & \multirow[t]{3}{*}{ البنود } & \multirow[t]{3}{*}{ م } \\
\hline & & & & \multicolumn{2}{|c|}{ موافق بشدة } & \multicolumn{2}{|c|}{ موافق } & \multicolumn{2}{|c|}{ محايد } & \multicolumn{2}{|c|}{ غير موافق } & \multicolumn{2}{|c|}{ غير موافق } & & \\
\hline & & & & نسبة & تكرار & نسبة & تكرار & نسبة & تكرار & نسبة & تكرار & نسبة & تكرار & & \\
\hline 1 & كبيرة & .,$\wedge \varepsilon 7$ & $\varepsilon, Y \cdot V$ & $\varepsilon r, \varepsilon$ & ra & $\varepsilon 1, r$ & ru & $1 ., 9$ & 1. & $0, \varepsilon$ & 0 & ., & ., & تحترص على ضريس المباشر قبل البدرء موافقة & 1 \\
\hline$r$ & متوسطة & 1,194 & r,qro & $\Lambda, \mathrm{V}$ & $\wedge$ & $\Gamma, 0$ & rq & $\mid \varepsilon, 1$ & ir & $r 0,9$ & r & $9, \wedge$ & 9 & 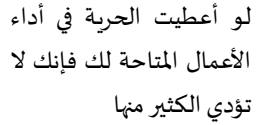 & r \\
\hline r & كبيرة & ., MAM & $r, 90 \mathrm{~V}$ & $r 7,1$ & $r \varepsilon$ & $0 \leqslant, \Gamma$ & 0. & $\Lambda, \vee$ & $\wedge$ & $1 ., 9$ & 1. & ., & .,. & 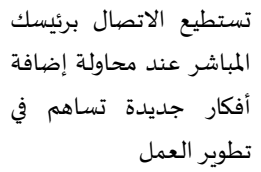 & $r$ \\
\hline$\varepsilon$ & متوسطة & 1,101 & $r, \Lambda \cdot \varepsilon$ & $1 ., 9$ & 1. & $17, r$ & 10 & $r r, q$ & rr & $\varepsilon, r$ & rv & $\Lambda, \mathrm{V}$ & $\wedge$ & 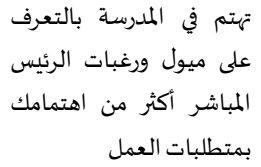 & $\varepsilon$ \\
\hline
\end{tabular}

يتضح من الجدول (7) أن مستوى الاغتراب الوظيفي لدى قادة المدارس الثانوية الحكومية في مدينة بريدة فيما يتعلق بفقدان السيطرة متحقق

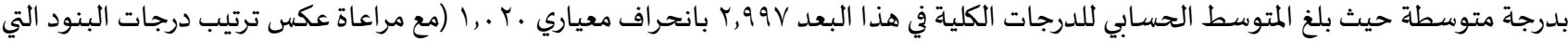
لا تعبر عن اغتراب وظيفي)، ويعزى ذلك إلى التقيد بخطط وتعليمات الرئيس المباشر أو المشرف نظراً لطبيعة الإدارة المركزية التي تعمل بها إدارة التعليم مما يفقد القادة القوة أو السيطرة لأدوارهم الوظيفية والإحساس بالعجز لعدم قدرتهم على اتخاذ القرار والإحساس بالعجز أمام الدور المناط بهم،

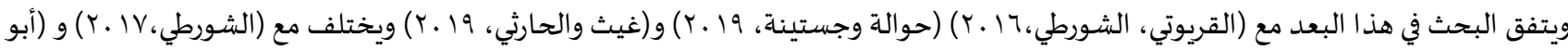

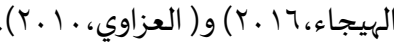

أما بشأن العبارات الفرعية في هذا البعد فجاءت مرتبة حسب داء درجة التحقق كالتالي: جاءت العبارة "تحرص على ضرورة موافقة الرئيس المباشر قبل البدء بتنفيذ الأعمال" في الترتيب الأول من حيث درجة التحقق، ومتحققة بدرجة

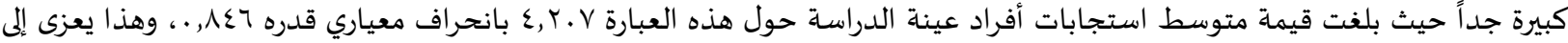
طبيعة نظام الإدارة المركزية في إدارات تعليم المملكة. جاءت العبارة "تستطيع الاتصال برئيسك المباشر عند محاولة إضافة أفكار جديدة تساهم في تطوير العمل" في الترتيب الثاني من حيث درجة التحقق، ومتحققة بدرجة كبيرة حيث بلغت قيمة متوسط استجابات أفراد عينة الدراسة حول هذه العبارة Y,90V بانحراف معياري قدره يMA, . ، وهذا يعزى لكثرة لطبيعة التواصل المستمر واليومي مع الرئيس المباشر لمتابعة تنفيذ الأعمال تبعاً لنظام الإدارة المركزية. جاءت العبارة "لو أعطيت الحرية في أداء الأعمال المتاحة لك فإنك لا تؤدي الكثير منها" في الترتيب الثالث من حيث درجة التحقق، ومتحققة

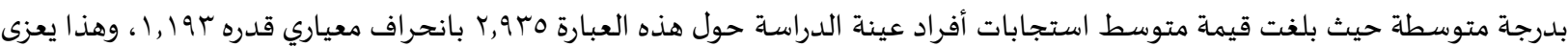
إلى تضارب الشعور لدى القادة بين إحسـاسهم بعدم القدرة على اتخاذ القرارت وبين احساسهم بالمسؤلية تجاه ماكلفوا باه. جاءت العبارة "تهتم في المدرسة بالتعرف على ميول ورغبات الرئيس المباشر أكثر من اهتمامك بمتطلبات العمل" في الترتيب الرابع من حيث درجة

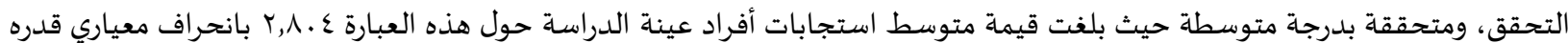


ا إ, ا، وهذا يعزى إلى أنه في الإدارات المركزية تعود السياسات والقوانين ومتطلبات العمل إلى الوزارة كإدارة عليا وليس لميول ورغبات الرئيس

المباشر الذي يقوم بدور السلطة التنفيذية.

ويمكن توضيح مستوى الاغتراب الوظيفي لدى قادة المدارس الثانوية الحكومية في مدينة بريدة فيما يتعلق بفقدان السيطرة من خلال الشكل

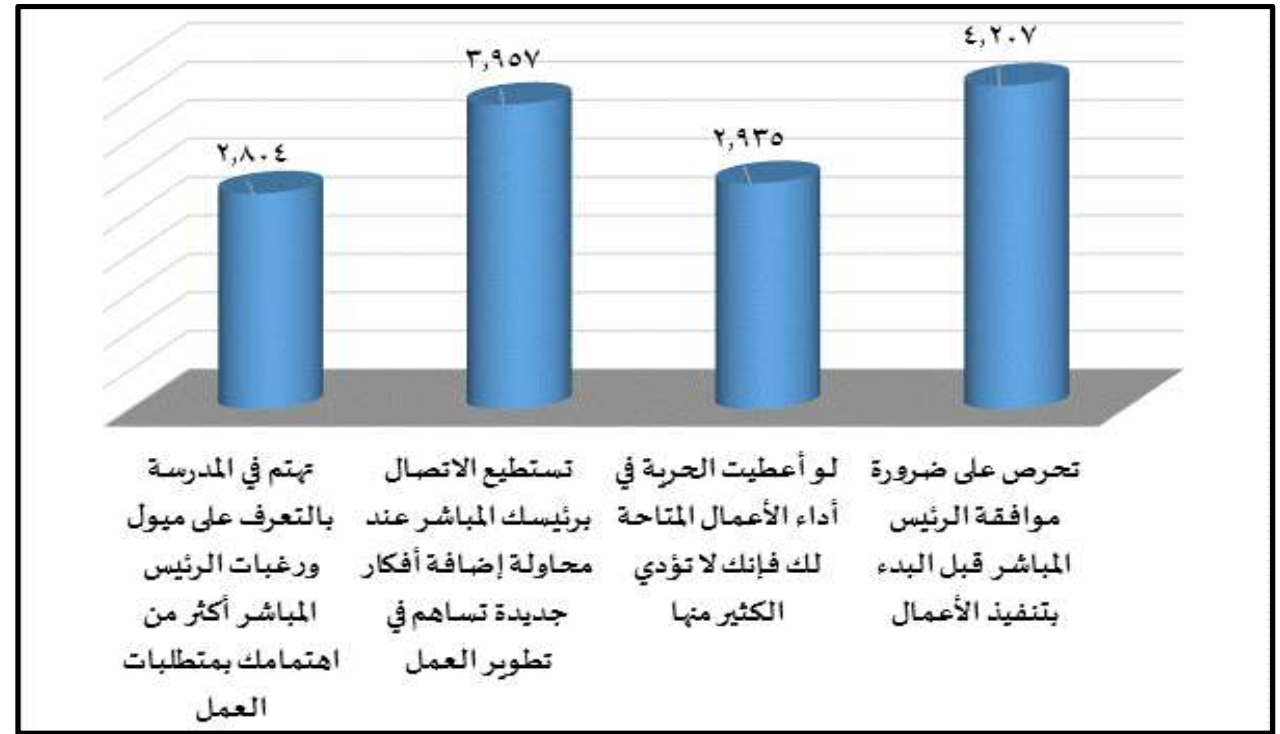

شكل (؟): مستوى الاغتراب الوظيفي لدى قادة المدارس الثانوية الحكومية في بريدة فيما يتعلق بفقدان السيطرة

r البعد الثاني: فقدان المعنى: البع:

\begin{tabular}{|c|c|c|c|c|c|c|c|c|c|c|c|c|c|c|c|}
\hline \multirow[t]{3}{*}{ الترتيب } & \multirow{3}{*}{ التحقق درجة } & \multirow{3}{*}{ المعياري } & \multirow{3}{*}{ المسابي } & \multicolumn{10}{|c|}{ الاستجابة } & \multirow[t]{3}{*}{ البنود } & \multirow[t]{3}{*}{ r } \\
\hline & & & & \multicolumn{2}{|c|}{ موافق بشدة } & \multicolumn{2}{|c|}{ موافق } & \multicolumn{2}{|c|}{ محايد } & \multicolumn{2}{|c|}{ غير موافق } & \multicolumn{2}{|c|}{ غير موافق } & & \\
\hline & & & & نسبة & تكرار & نسبة & تكرار & نسبة & تكرار & نسبة & تكرار & نسبة & تكرار & & \\
\hline$r$ & كبيرة &., 991 & $r, 070$ & $1 r,$. & Ir & $O T, Y$ & $\varepsilon \wedge$ & $10, Y$ & $1 \varepsilon$ & $\mid V, \varepsilon$ & 17 & $T, Y$ & r & العمل الذي تمارسـه حالياً & 1 \\
\hline$\varepsilon$ & متوسطة & $1, r \ldots$ & $r, 410$ & $r \cdot, V$ & 19 & $r \Lambda, r$ & r & $T V, r$ & ro & $৭, \curlywedge$ & 9 & $1 \leqslant, 1$ & ir & تشارك بوضع وتنفيذ & r \\
\hline 1 & كبيرة & $\cdot, V 7 \varepsilon$ & $\varepsilon, r \circ 9$ & 01,1 & $\varepsilon V$ & $r 0,9$ & $r$ & $1 ., 9$ & 1. & T,Y & r & ., & $\cdot$, & عندمن يسودك شملك بشور & $r$ \\
\hline r & كبيرة & $\cdot, \wedge V_{0}$ & $\varepsilon, 1 Y$. & rT, & r. & $o v, 7$ & or & .,. &., & $\curlywedge, \mathrm{V}$ & $\wedge$ & 1,1 & 1 & والافتخار بنتائج عملك الاعتزاز & $\varepsilon$ \\
\hline \multicolumn{2}{|c|}{ ضعيفة } &., $9 \wedge \varepsilon$ & r.17. & \multicolumn{12}{|c|}{ المتوسط العام لبعد فقدان المعنى } \\
\hline
\end{tabular}

يتضح من الجدول السـابق أن مستوى الاغتراب الوظيفي لدى قادة المدارس الثانوية الحكومية في مدينة بريدة فيما يتعلق بفقدان المعنى متحقق بدرجة ضعيفة (عبارات هذا البعد جميعها معكوسة وارتفاع درجاتها يعبر عن انخفاض الاغتراب الوظيفي) حيث بلغ المتوسط الحسابي للدرجات التوات الكلية في هذا البعد . 7 ا, ب بانحراف معياري عـ9, ..، ويعزى ذلك إلى إلتزام القادة بالأعمال الموكلة لهم وتنفيذ السياسات العليا للإدارة لتحقيق الأهداف

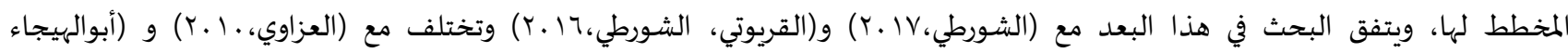

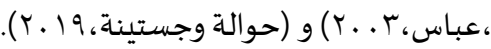

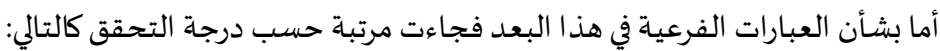
جاءت العبارة "عندما تنجز عملك بشكل متقن يسودك شعور بالفخر والاعتزاز" في الترتيب الأول من حيث درجة التحقق، ومتحققة بدرجة كبيرة

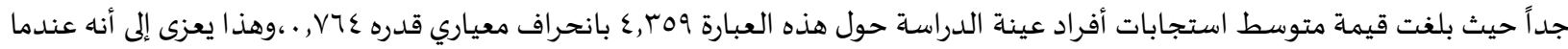
يحقق القادة أهد افهم أو ينجزون أعمالهم بشكل متقن فإنهم يصلون إلى مرحلة الاعتزاز والتفاخر التي تشبع حاجتهم كبشر إلى التقدير والوصيول للتميز والكمال. 
جاءت العبارة "يتملكك شعور بالاعتزاز والافتخار بنتائج عملك الحالي" في الترتيب الثاني من حيث درجة التحقق، ومتحققة بدرجة كبيرة حيث

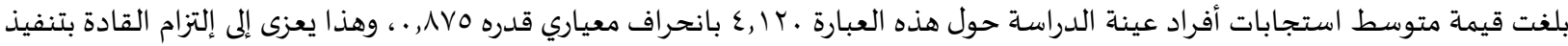
الأعمال الموكلة لهم.

جاءت العبارة "العمل الذي تمارسـه حالياً يلبي طموحاتك" في الترتيب الثالث من حيث درجة التحقق، ومتحققة بدرجة كبيرة حيث بلغت قيمة متوسط استجابات أفراد عينة الدراسة حول هذه العبارة 070, ب بانحراف معياري قدره 999, .9 ، ، وهذا يعزى إلى أن القائد هو صاحب أعلى مرتبة وظيفية في المدرسة ولا يستطيع الوصهول إلى هذا المنصب إلا بعد خبرة عدة سنوات بالإضيافة إلى اختبار القياس الخاص باص بالقادة. جاءت العبارة "تشارك بوضع وتنفيذ سياسات العمل" في الترتيب الرابع من حيث درجة التحقق، ومتحققة بدرجة متوسطة حيث بلغت قيمة

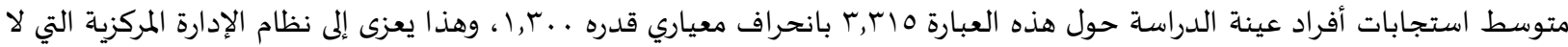
تشجع على المبادرة والابتكار وتتسم بالجمود. ويمكن توضيح مستوى الاغتراب الوظيفي لدى قادة المدارس الثانوية الحكومية في مدينة بريدة فيما يتعلق بفقدان المعنى من خلال الشكل (ع):

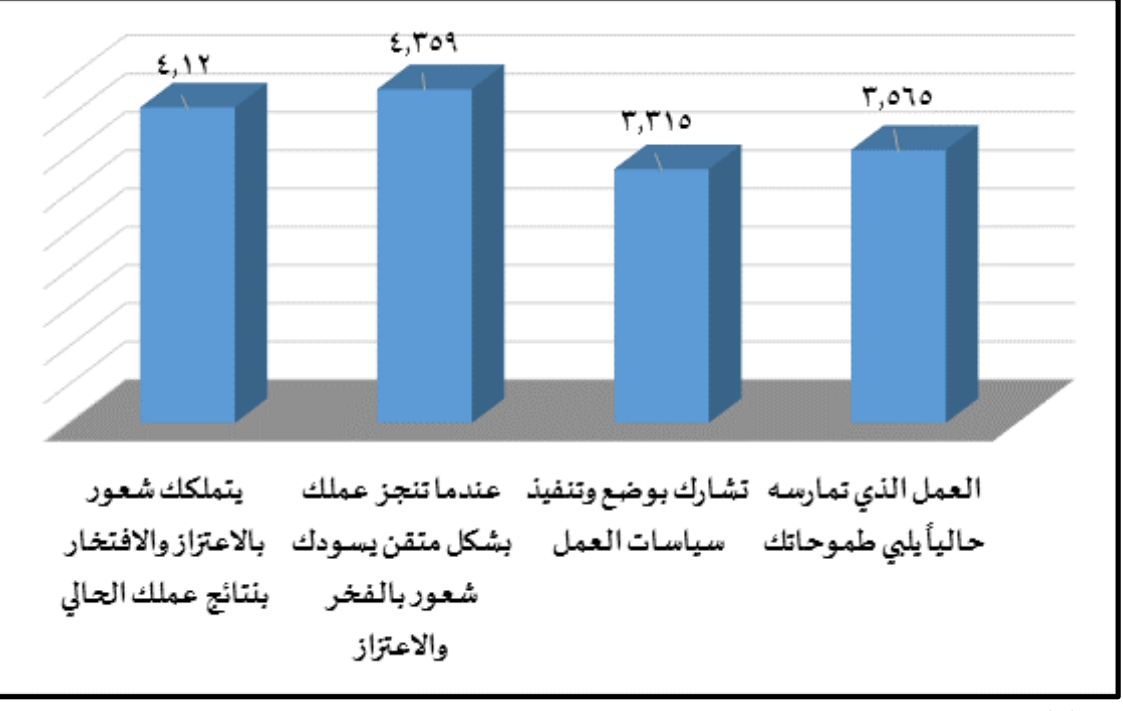

شكل (ع): مستوى الاغتراب الوظيفي لدى قادة المدارس الثانوية الحكومية في بريدة فيما يتعلق بفقدان المعنى

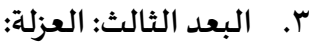

جدول (^): التكرارات والنسب المئوية والمتوسطات والانحر افات المعيارية لاستجابات عينة البحث على بعد العزلة

\begin{tabular}{|c|c|c|c|c|c|c|c|c|c|c|c|c|c|c|c|}
\hline \multirow[t]{3}{*}{ الترتيب } & \multirow{3}{*}{ التحقق درجة } & \multirow{3}{*}{ المعياري } & \multirow{3}{*}{ الحسابي } & \multicolumn{10}{|c|}{ الاستجابة } & \multirow[t]{3}{*}{ العبارات } & \multirow[t]{3}{*}{ م } \\
\hline & & & & \multicolumn{2}{|c|}{ موافق بشدة } & \multicolumn{2}{|c|}{ موافق } & \multicolumn{2}{|c|}{ محايد } & \multicolumn{2}{|c|}{ غير موافق } & \multicolumn{2}{|c|}{ غير موافق } & & \\
\hline & & & & نسبة & 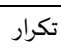 & نسبة & تكرار & نسبة & تكرار & نسبة & تكرار & نسبة & تكرار & & \\
\hline 0 & ضعيفة & $1, r .9$ & r,o.. & $0, \varepsilon$ & 0 & $r \cdot, V$ & 19 & $10, Y$ & $1 \varepsilon$ & $r 0,9$ & r & $r T, \Lambda$ & ri & تشعر بالرغبة في البقاء في & 1 \\
\hline$\varepsilon$ & متوسطة & $1, . v 9$ & $r, 7.9$ & $\varepsilon, r$ & $\varepsilon$ & $r T, \Lambda$ & rI & Ir,. & 11 & 01,1 & $\varepsilon V$ & $9, \wedge$ & 9 & يسود العمل ضعف في روح & r \\
\hline$r$ & متوسطة & . 9 qrV & r,qYA & $0, \varepsilon$ & 0 & m., & $T \varepsilon$ & $r q, r$ & TV & $r q, 1$ & $r$ & $\cdot$, & $\cdot, \cdot$ & علاقاتك مع أفراد خارج & $r$ \\
\hline 1 & كبيرة &.,$\lambda .0$ & $r, 97 \mathrm{~V}$ & $r Y, \Lambda$ & rI & $\Delta \wedge, \vee$ & $0 \varepsilon$ & $1 ., 9$ & 1. & $v, 7$ & $\checkmark$ &., &., & تشعر بالانتماء الفعلي لفرق & $\varepsilon$ \\
\hline$r$ & متوسطة & $1,1 T \Lambda$ & r,vrq & $v, 7$ & v & 19,7 & 11 & $r T, \Lambda$ & $r$ & $r q, 1$ & $r$ & $1 ., 9$ & 1. & صلا تميل إلى تكوين علاقات & 0 \\
\hline \multicolumn{2}{|c|}{ ضعيفة } & $1, . r 1$ & T,OVY & \multicolumn{12}{|c|}{ المتوسط العام لبعد العزلة } \\
\hline
\end{tabular}


يتضح من الجدول السـابق أن مستوى الاغتراب الوظيفي لدى قادة المدارس الثانوية الحكومية في مدينة بريدة فيما يتعلق بالعزلة متحقق بدرجة

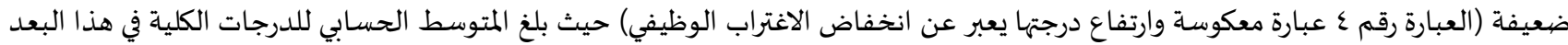

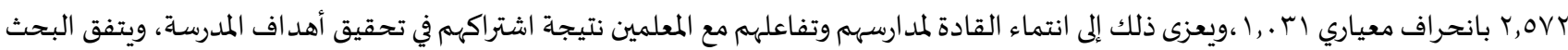

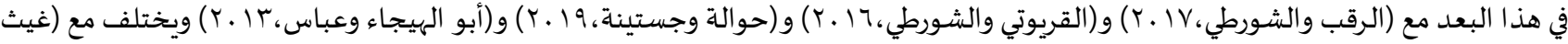

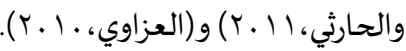

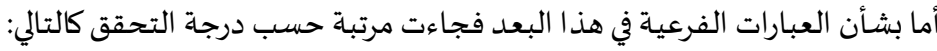
جاءت العبارة "تشعر بالانتماء الفعلي لفرق العمل" في الترتيب الأول من حيث درجة التحقق، ومتحققة بدرجة كبيرة حيث بلغت قيمة متوسط

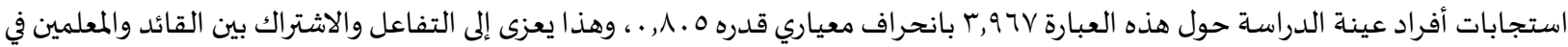
وضيع الخطط وتنفيذها. جاءت العبارة "ترغب في أن تكون معظم علاقاتك مع أفراد خارج محيط العمل" في الترتيب الثاني من حيث درجة التحقق، ومتحققة بدرجة

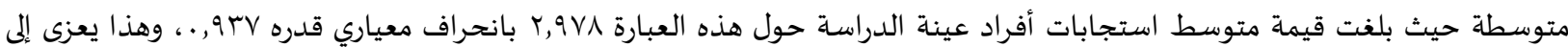
الإنسان يميل إلى أن يكون أكثر تقبلاً للأشخاص الذين تربطهم باء سنين طويلة على عكس العلاقات في الوظيفة غالباً ماتكون علاقات سطحية

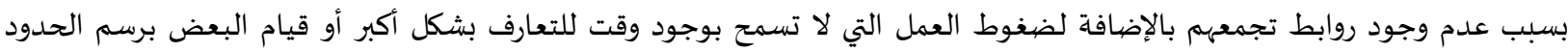
والحواجز. جاءت العبارة "لا تميل إلى تكوين علاقات صداقة ضمن محيط عملك الحالي" في الترتيب الثالث من حيث درجة التحقق، ومتحققة بدرجة

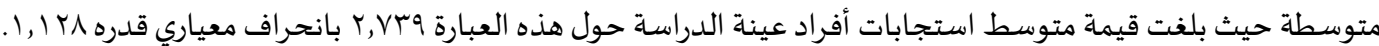
جاءت العبارة "يسود العمل ضعف في روح التعاون بين العاملين في المدرسة" في الترتيب الرابع من حيث درجة التحقق، ومتحققة بدرجة متوسطة

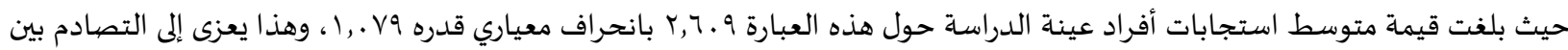
بعض القادة ومعلميهم نتيجة الاختلاف في التوجهات والآراء أو عدم تقبل الأوامر. جاءت العبارة "تشعر بالرغبة في البقاء في المنزل بدلاً من الذهاب إلى العمل" في الترتيب الخامس من حيث درجة التحقق، ومتحققة بدرجة ضعيفة

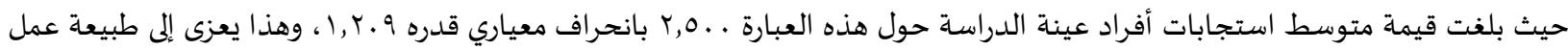
القادة ومسؤلياتهم التي لا تسمح لهم بالغياب عن المدرسـة، بالإضافة أن العمل يحقق شعور الإشباع النفسي بالأهمية والإنتاجية . ويمكن توضيح مستوى الاغتراب الوظيفي لدى قادة المدارس الثانوية الحكومية في مدينة بريدة فيما يتعلق بالعزلة من خلال الشكل (ه):

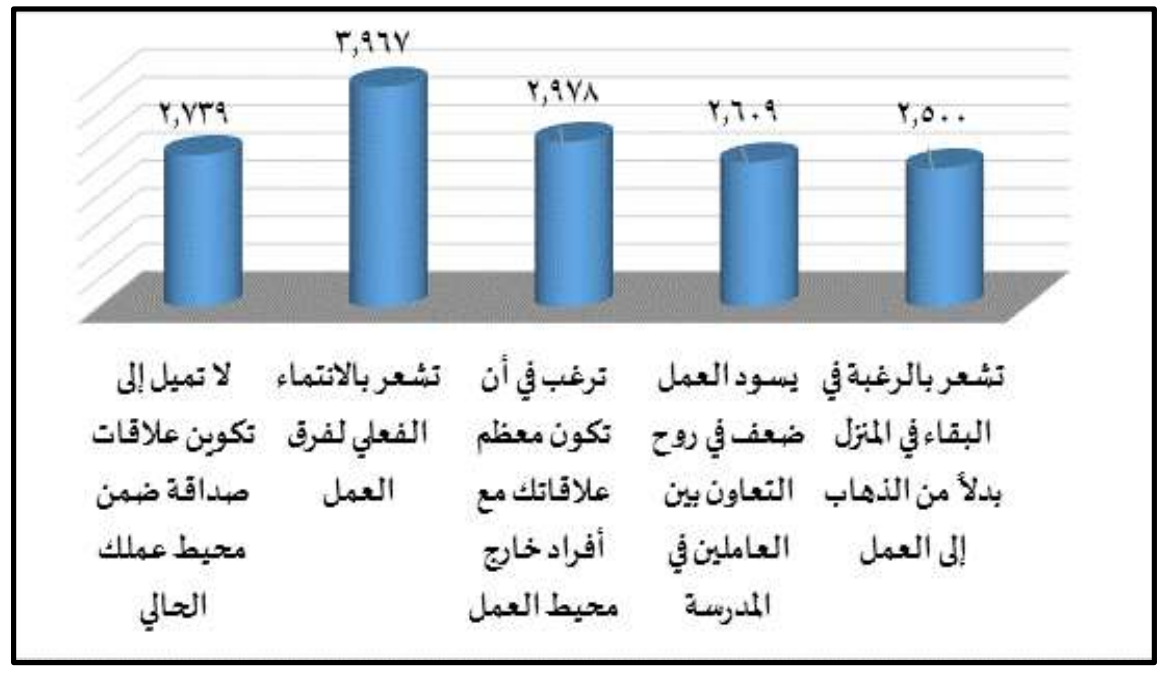

شكل (ه): مستوى الاغتراب الوظيفي لدى قادة المدارس الثانوية الحكومية في بريدة فيما يتعلق بالعزلة 
ع. البعد الر ابع: اللامعيارية:

جدول (9): التكرارات والنسب المئوية والمتوسطات والانحر افات المعيارية لاستجابات عينة البحث على بعد اللامعيارية

\begin{tabular}{|c|c|c|c|c|c|c|c|c|c|c|c|c|c|c|c|}
\hline \multirow[t]{3}{*}{ الترتيب } & \multirow{3}{*}{ التحقق } & \multirow{3}{*}{ المعياري } & \multirow{3}{*}{ المتوسط الحسبابي } & \multicolumn{10}{|c|}{ الاستجابة } & \multirow[t]{3}{*}{ البنود } & \multirow[t]{3}{*}{ م } \\
\hline & & & & \multicolumn{2}{|c|}{ موافق بشدة } & \multicolumn{2}{|c|}{ موافق } & \multicolumn{2}{|c|}{ محايد } & \multicolumn{2}{|c|}{ غير موافق } & \multicolumn{2}{|c|}{ غير موافق } & & \\
\hline & & & & نسبة & تكرار & نسبة & تكرار & نسبة & تكرار & نسبة & تكرار & نسبة & تكرار & & \\
\hline 1 & كبيرة & 1,Irr & $r, 00 \varepsilon$ & $r, \Lambda$ & rI & ro, 9 & r & $17, r$ & 10 & $r r, q$ & Tr & 1,1 & 1 & تلاستغر بأنك تعثراً في أثناء & 1 \\
\hline$r$ & متوسطة & $1,1 \leqslant 0$ & r,人rT & $10, r$ & $1 \varepsilon$ & $V, T$ & V & $r 7,1$ & $r \varepsilon$ & $\varepsilon 7, V$ & $\varepsilon r$ & $\varepsilon, r$ & $\varepsilon$ & 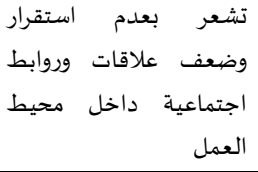 & r \\
\hline$\varepsilon$ & ضعيفة & 1,191 & $r, \varepsilon r_{0}$ & $9, \wedge$ & 9 & $1 ., 9$ & 1. & $1 ., 9$ & 1. & $0 .,$. & $\varepsilon 7$ & 11,0 & IV & تعاني & $r$ \\
\hline 0 & ضعيفة & 1,109 & T, YYA & $9, \wedge$ & 9 & $\varepsilon, r$ & $\varepsilon$ & $\Lambda, \vee$ & $\wedge$ & or,r & $\varepsilon 9$ & $r, q$ & rt & تعلى وشك بأن العالم من حولك & $\varepsilon$ \\
\hline r & متوسطة & $1,1 V 9$ & $r, 17 r$ & $1 ., 9$ & 1. & $r \varepsilon, \lambda$ & rt & ro,. & זr & 11,0 & IV & $1 ., 9$ & 1. & ومعايير موضيوعية عادلة التحفيز على أسس & 。 \\
\hline طة & 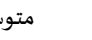 & 1,171 & $r, V \vee\urcorner$ & & & & & & رية & حد || & & المتو & & & \\
\hline
\end{tabular}

يتضح من الجدول السـابق أن مستوى الاغتراب الوظيفي لدى قادة المدارس الثانوية الحكومية في مدينة بريدة فيما يتعلق باللامعيارية متحقق بدرجة متوسطة (العبارة رقم ه عبارة معكوسة وارتفاع درجتها يعبر عن انخفاض الاغتراب الوظيفي) حيث بلغ المتوسط الحسابي للدرجات الكلية في هذا

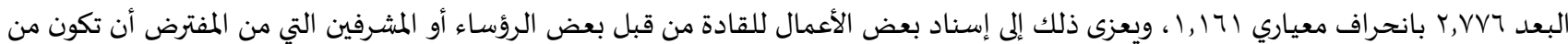
اختصاصهم وتتفق هذه النتيجة مع (حوالة،جستينة،و، 19) التي وضحت أن عدم الشفافية والوضوح في المنافسة والتشجيع وعدم وضوح بنود

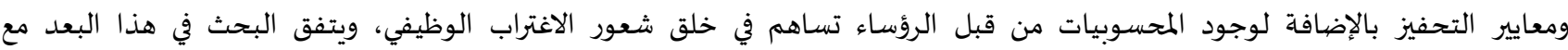

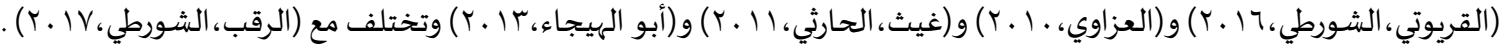

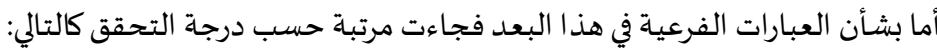
جاءت العبارة "تشعر بأنك تعرضت للاستغلال كثيراً في أثناء العمل" في الترتيب الأول من حيث درجة التحقق، ومتحققة بدرجة كبيرة حيث بلغت

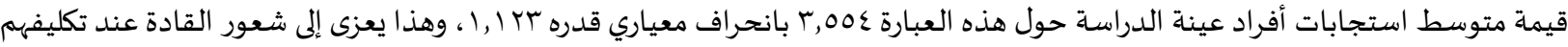
بأعمال تكون خاصة بالمشرفين أو الرؤساء في إدارة التعليم. جاءت العبارة "يتم التحفيز على أسس ومعايير موضوعية عادلة" في الترتيب الثاني من حيث درجة التحقق، ومتحققة بدرجة متوسطة حيث

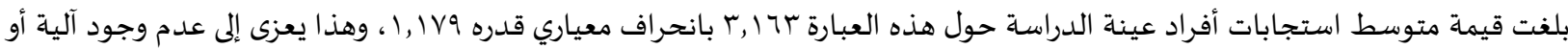
معايير للحوافز التي تقدم للقائد من قبل الرئيس المباشر. جاءت العبارة "تشعر بعدم استقرار وضعف علاقات وروابط اجتماعية داخل محيط العمل" في الترتيب الثالث من حيث درجة التحقق،

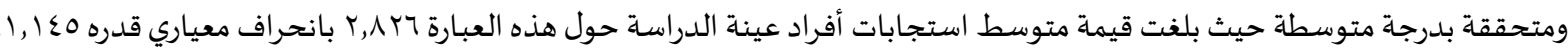
جاءت العبارة "تعاني كثيراً من الوحدة/العزلة حتى إذا كنت وسط زملائك في العمل" في الترتيب الرابع من حيث درجة التحقق، ومتحققة بدرجة

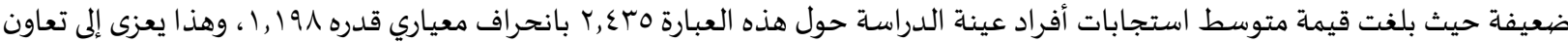

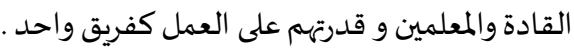
جاءت العبارة "تعتقد بأن العالم من حولك على وشك التمزق" في الترتيب الخامس من حيث درجة التحقق، ومتحققة بدرجة ضعيفة حيث بلغت

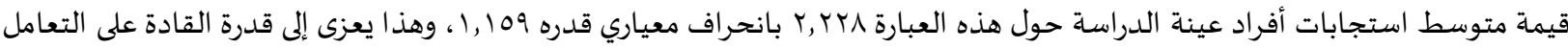

مع الضغوط والمشاعر السلبية نتيجة خبرتهم العملية.

ويمكن توضيح مستوى الاغتراب الوظيفي لدى قادة المدارس الثانوية الحكومية في مدينة بريدة فيما يتعلق باللامعيارية من خلال الشكل (7): 


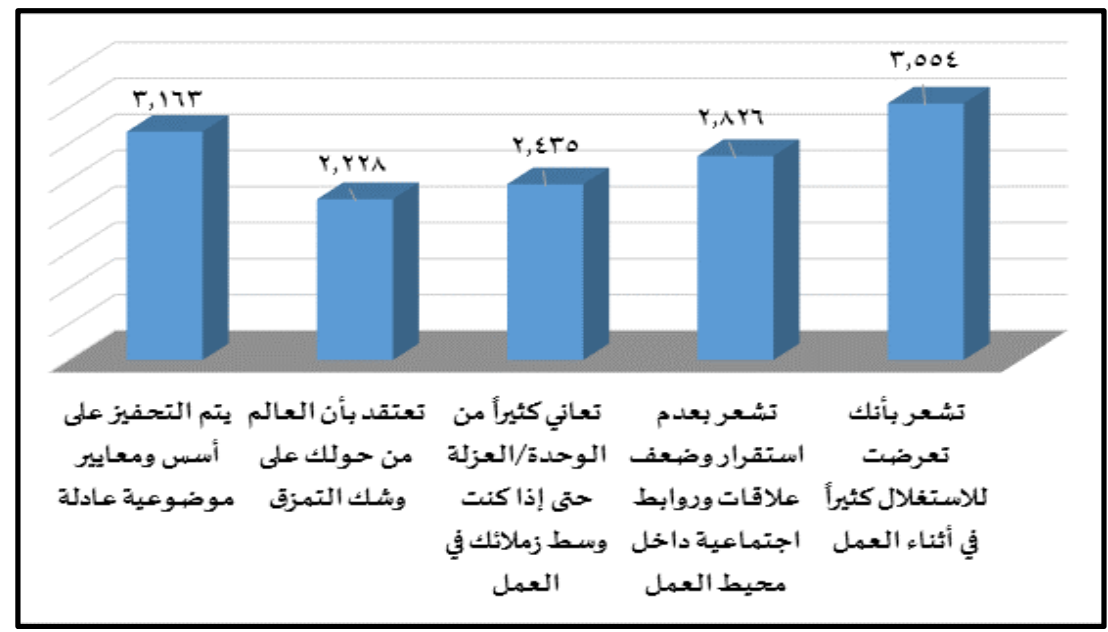

شكل (7): مستوى الاغتراب الوظيفي لدى قادة المدارس الثانوية الحكومية في بريدة فيما يتعلق باللامعيارية

ومجمل ما تم التوصل إليه من نتائج فيما يتعلق بمستوى الاغتراب الوظيفي لدى قادة المدارس الثانوية الحكومية في مدينة بريدة يمكن تلخيصيه

في الجدول (1) (1):

جدول ( ـ (): مستوى الاغتراب الوظيفي لدى قادة المدارس الثانوية الحكومية في مدينة بريدة

\begin{tabular}{|c|c|c|c|c|c|}
\hline الترتيب & المئوبة & التحقق & المعياري & الحسابي & الاغتراب الوظيفي لدى قادة المدارس الثانوية الحكومية \\
\hline 1 & $\%$ & متوسطة & 1,.r. & $r, 99 \mathrm{~V}$ & فقدان السيطرة \\
\hline$\varepsilon$ & $\%$ \% & ضعيفة &., $9 \wedge \varepsilon$ & r,17. & فقدان المعنى \\
\hline$r$ & $\% 01$ & ضعيفة & $1, . \pi 1$ & T,OVT & العزلة \\
\hline r & $\% 00$ & متوسطة & 1,171 & r,VV7 & اللامعيارية \\
\hline & $\%$ \% & متوسطة & $1, . \leqslant 9$ & $r, 7 \uparrow 7$ & الدرجة الكلية لمستوى الاغتراب الوظيفي \\
\hline
\end{tabular}

يتضح من الجدول السابق أن مستوى الاغتراب الوظيفي لدى قادة المدارس الثانوية الحكومية في مدينة بريدة جاء متحققاً بدرجة متوسطة أقرب

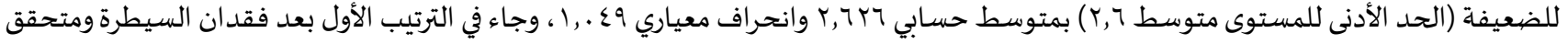

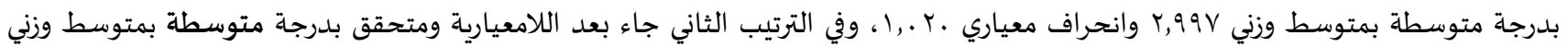

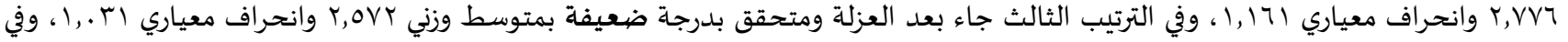

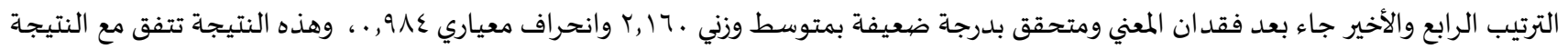

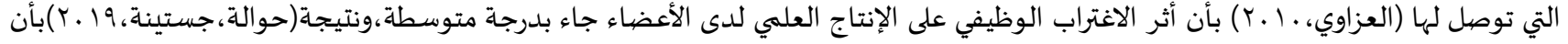

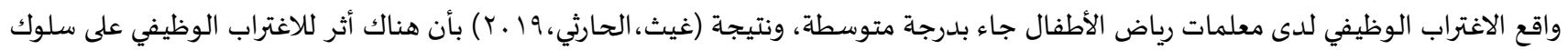

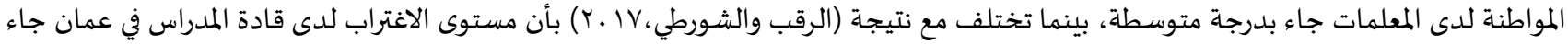

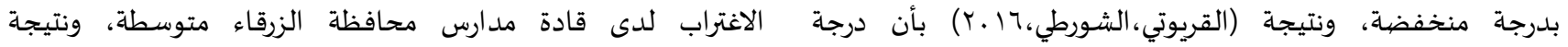

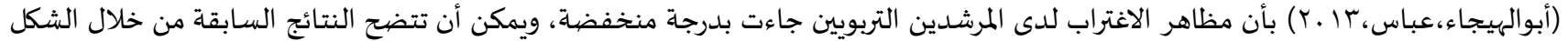




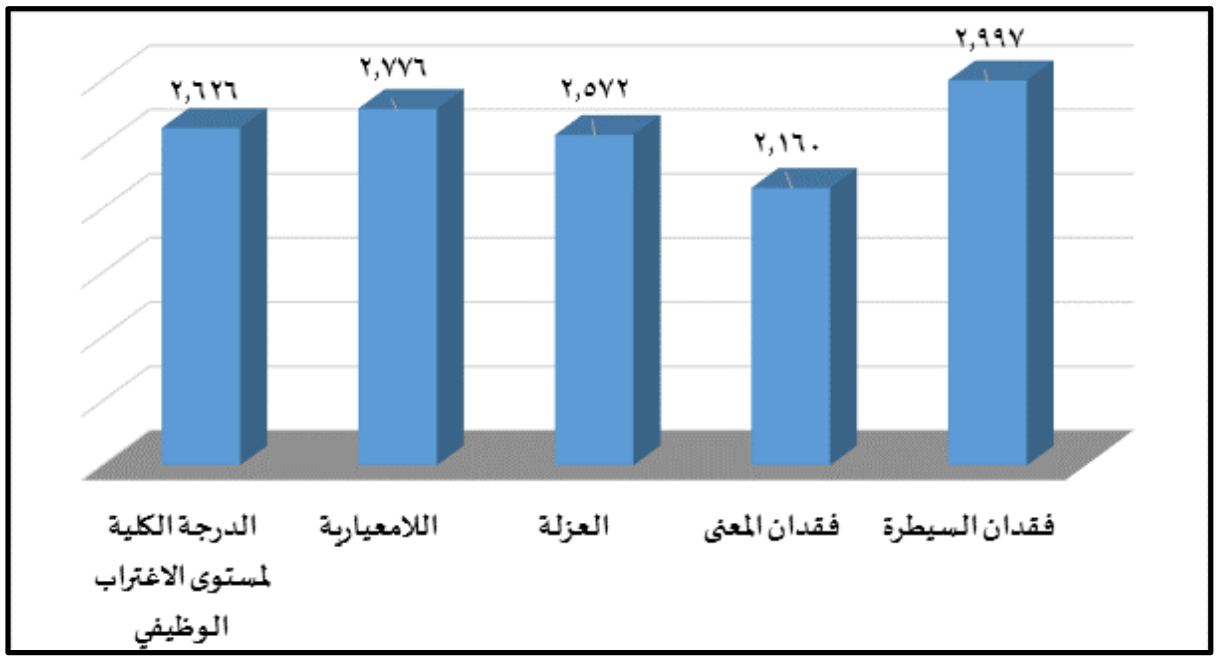

شكل (V): مستوى الاغتراب الوظيفي لدى قادة المدارس الثانوية الحكومية في مدينة بريدة

ثانياً: نتائج إجابة السؤال الثاني: ينص السؤال الثاني للبحث الحالي على "هل توجد فروق ذات دلالة إحصائية في مستوى الاغتراب الوظيفي لدى قادة المدارس الثانوية الحكومية في مدينة بريدة تعزى لمتغيرات (الجنس، سنواتهات التهوات الخبرة)؟". يمكن عرض النتائج حسب كل كتغير كالتالي: 1 أ. بالنسبة لمتغير الجنس: تم استخدام اختبار "ت" للمجموعات المستقلة Independent Samples T-Test في الكشف عن دلالة الفروق في مستوى الاغتراب الوظيفي لدى قادة المدارس الثانوية الحكومية في بريدة والتي ترجع لاختلاف الجنس (ذكر ، أنثى) فكانت النتائج كما هي موضحة في في التالي:

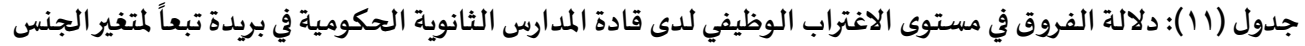

\begin{tabular}{|c|c|c|c|c|c|c|}
\hline مستوى الدلالة & قيمة "ت" & الانحراف المعياري & المتوسط الحسابي & درجات الحرية & الجنس & مستوى الاغتراب الوظيفي \\
\hline \multirow[t]{2}{*}{., .1} & \multirow[t]{2}{*}{$\varepsilon, 7 \ldots$} & $r, .9 r$ & IT,ATV & \multirow[t]{2}{*}{9.} & ذكر & \multirow[t]{2}{*}{ فقدان السيطرة } \\
\hline & & 1,101 & $1 ., 9 \ldots$ & & إناث & \\
\hline \multirow[t]{2}{*}{.,. $\mathrm{VV}$} & \multirow[t]{2}{*}{ l,VAV } & r, tru & $9, .01$ & \multirow[t]{2}{*}{9.} & ذكر & \multirow[t]{2}{*}{ فقدان المعنى } \\
\hline & & r,VVT & $\Lambda, 1 \ldots$ & & إناث & \\
\hline \multirow[t]{2}{*}{.,Ort } & \multirow[t]{2}{*}{$\cdot, 7 \uparrow \Lambda$} & $r, 70 \varepsilon$ & $1 r, .01$ & \multirow[t]{2}{*}{9.} & ذكر & \multirow[t]{2}{*}{ 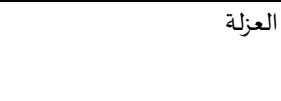 } \\
\hline & & $r, r \cdot q$ & $\mid r, 7 \ldots$ & & إناث & \\
\hline \multirow[t]{2}{*}{., .1} & \multirow[t]{2}{*}{$r, £ \vee\urcorner$} & $r, q r \varepsilon$ & $1 \varepsilon, 179$ & \multirow[t]{2}{*}{9.} & ذكر & \multirow[t]{2}{*}{ اللامعيارية } \\
\hline & & $r, 917$ & IT,VTO & & إناث & \\
\hline \multirow[t]{2}{*}{., .1} & \multirow[t]{2}{*}{$r, V \cdot r$} & $9, £ \wedge 0$ & $\varepsilon q, V \backslash r$ & \multirow[t]{2}{*}{$q$. } & ذكر & \multirow[t]{2}{*}{ الدرجة الكلية للاغتراب الوظيفي } \\
\hline & & $9, \varepsilon 7 \varepsilon$ & $\varepsilon \varepsilon, \Gamma_{0}$ & & إناث & \\
\hline
\end{tabular}

يتضح من الجدول (1 (1) أنه توجد فروق دالة إحصائياً عند مستوى ثقة ا .,. في مستوى الاغتراب الوظيفي لدى قادة المدارس الثانوية الحكومية في مدينة بريدة فيما يتعلق بالدرجة الكلية وبعدي (فقدان السيطرة واللامعيارية) ترجع لاختلاف الجنس، والفروق لصالح الذكور، بينما لا توجد فروق د الة إحصائياً في مستوى فقدان المعنى والعزلة كأبعاد للاغتراب الوظيفي لدى قادة المدارس الثانوية الحكومية في مدينة ترجع لاختلاف الجنس. والنتائج هنا تؤكد في مجملها أن الذكور من قادة المدارس الثانوية الحكومية في بريدة أعلى من الإناث في فقدان السيطرة واللامعيارية كمؤشرات

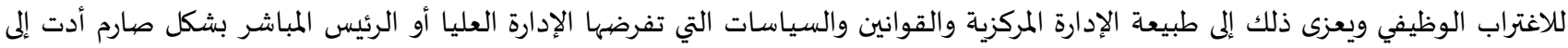
تقليص دور القادة وسلب إرادتهم وعدم منح الحرية لهم في اتخاذ القرارات وهذا يتنافى مع طبيعة الذكور فالإناث أكثر امتثالاً للأوامر وتطبيقاً للقوانين

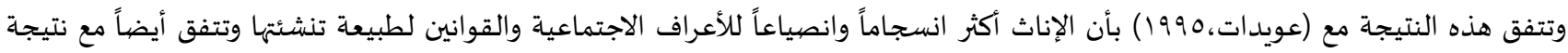
دراسة (Verma, 2017) التي أشارت إلى المعلمين أكثر شعوراً بالغربة من المعلمات، بينما كانت الفروق بين الذكور والإناث في مستوى فقدان المعنى

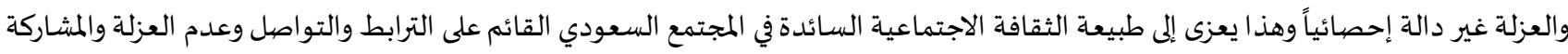
الاجتماعياة، وشعورهم بالرضا عن أنفسهم ومايقومون باه من أعمال لدى كل من الذكور والإناث وهذا يتفق مع توصل إليه كل من

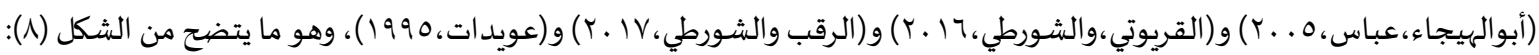




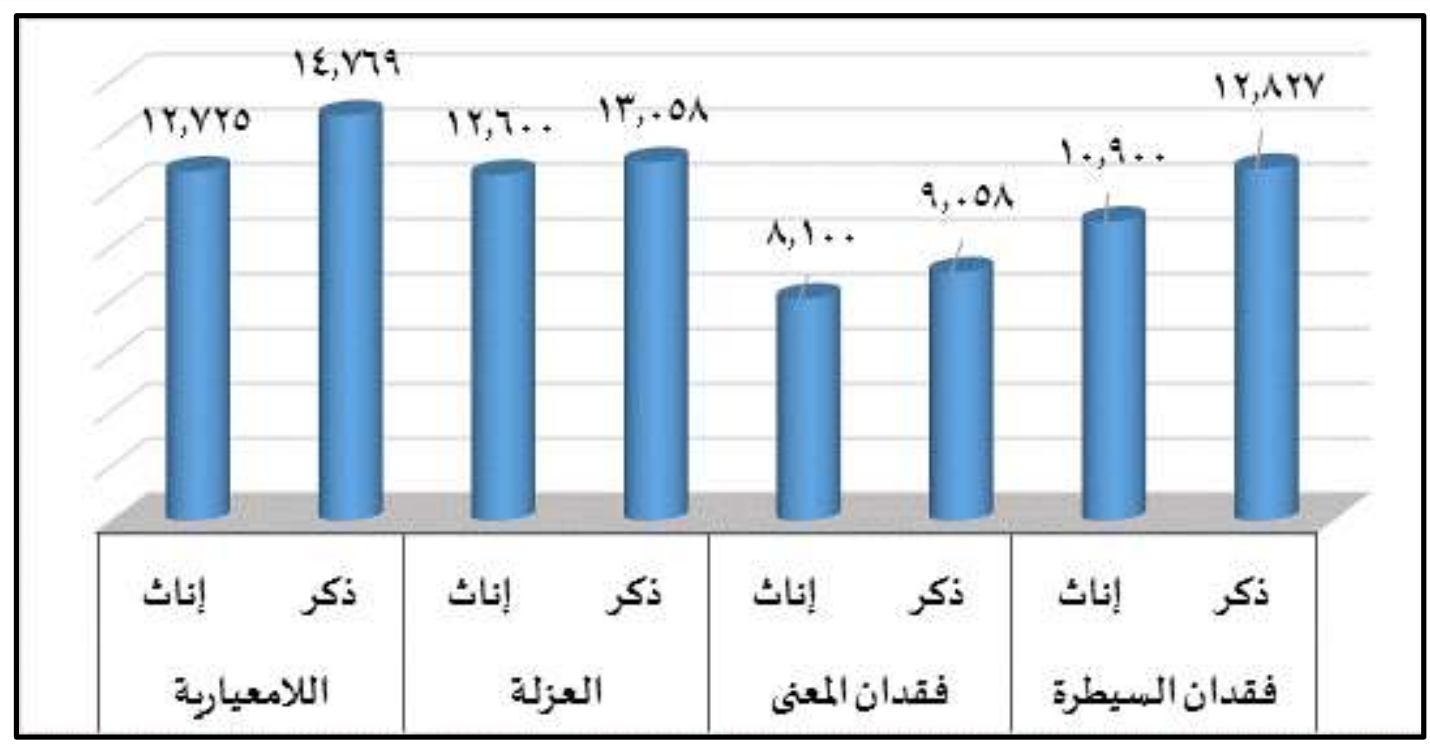

شكل (^): الفروق بين الذكوروالإناث من قادة المدارس الثانوية الحكومية ببريدة في الاغتراب الوظيفي

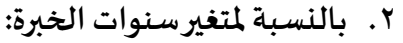

تم استخدام اختبار تحليل التباين أحادي الاتجاه One Way ANOVA في الكشف عن دلالة الفروق في مستوى الاغتراب الوظيفي لدى قادة

المدارس الثانوية الحكومية في مدينة بريدة والتي ترجع لاختلاف سنوات الخبرة (أقل من ه سنوات، من ه سنوات إلى أقل من · ا سنوات، من • إسنوات

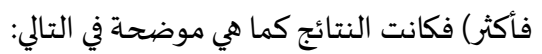

جدول (r ا ): المتوسطات والانحر افات لمستوى الاغتراب الوظيفي لدى قادة المدارس الثانوية الحكومية وفقاً لسنوات الخبرة

\begin{tabular}{|c|c|c|c|c|c|c|}
\hline \multicolumn{6}{|c|}{ سنوات الخبرة } & \multirow[t]{3}{*}{ مستوى الاغتراب الوظيفي } \\
\hline \multicolumn{2}{|c|}{ من · ا فأكثر } & \multicolumn{2}{|c|}{ من ه إلى أقل من -1 } & \multicolumn{2}{|c|}{ أقل من } & \\
\hline انحراف معياري & متوسط & انحراف معياري & متوسط & انحراف معياري & متوسط & \\
\hline T, rYT & $1 Y, .91$ & $\cdot, 9 \leqslant V$ & $1 \cdot$, Avo & $r, \Sigma) T$ & Ir,tro & فقدان السيطرة \\
\hline r,乏AV & 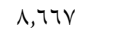 & r,ror & ᄉ,人זr & $r, r / 7$ & $\Lambda, r q \varepsilon$ & فقدان المعنى \\
\hline$r, \wedge 0 \mathrm{~V}$ & $\mid r, V \leqslant 0$ & r,TIT & $1 r, . \varepsilon r$ & $r, \varepsilon \ldots$ & $\mid r, 9 \leq 1$ & 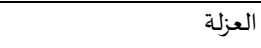 \\
\hline$r$, , OV & $\mid r, 7 \varepsilon V$ & $\varepsilon, r q \Lambda$ & $1 \varepsilon, . \varepsilon r$ & $\varepsilon, r V T$ & IE, ror & اللامعيارية \\
\hline $1 ., 290$ & $\varepsilon V, 10 \mathrm{~V}$ & $\Lambda, . \vee$. & ¿7, V१९ & $1 ., r \geq \vee$ & $\varepsilon \Lambda, \Lambda \uparrow \varepsilon$ & الدرجة الكلية \\
\hline
\end{tabular}

جدول (rآ ): دلالة الفروق في مستوى الاغتراب الوظيفي لدى قادة المدارس الثانوية الحكومية في بريدة تبعاً لاختلاف سنوات الخبرة

\begin{tabular}{|c|c|c|c|c|c|c|}
\hline مستوى الدلالة & "F" قيمة " & متوسط المربعات & درجات الحرية & مجموع المربعات & مصدر التباين & الاغتراب الوظيفي \\
\hline \multirow{3}{*}{,., 1} & \multirow[t]{3}{*}{$7,0 \vee 1$} & $r \Lambda, r q \Lambda$ & $r$ & $07, \vee 97$ & بين المجموعات & \multirow{3}{*}{ فقدان السيطرة } \\
\hline & & $\varepsilon, r \mid V$ & 19 & $r_{\Lambda \varepsilon, 19 \varepsilon}$ & داخل المجمموعات & \\
\hline & & & 91 & $\varepsilon \varepsilon ., 9 \wedge q$ & الكلي & \\
\hline \multirow{3}{*}{ 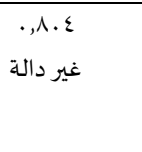 } & \multirow[t]{3}{*}{.,$Y 19$} & l,£ᄉr & r & r, $97 \mathrm{~V}$ & بين المجموعات & \multirow[t]{3}{*}{ فقدان المعنى } \\
\hline & & $7, \vee 777$ & 19 & $7 . Y, 197$ & داخل المجموعات & \\
\hline & & & 91 & $7.0,17 \pi$ & الكلي & \\
\hline \multirow{3}{*}{ غير دالة } & \multirow[t]{3}{*}{., .70} & V^9. & r & $1,0 \mathrm{VV}$ & بين المجموعات & \multirow[t]{3}{*}{ العزلة } \\
\hline & & 15,191 & 19 & $1.10,017$ & داخل المجمموعات & \\
\hline & & & 91 & $1 . \wedge V, 17 r$ & الكلي & \\
\hline \multirow{3}{*}{ غير دالة • ه م } & \multirow[t]{3}{*}{. TIV } & $r, 099$ & r & $V, 19 \mathrm{~V}$ & بين المجموعات & \multirow[t]{3}{*}{ الللامعيارية } \\
\hline & & $17,07 \mathrm{~V}$ & 19 & $\mid \leqslant \vee \varepsilon, \varepsilon \wedge \Lambda$ & داخل المجموعات & \\
\hline & & & 91 & $\mid \varepsilon \wedge 1,710$ & الكلي & \\
\hline \multirow{3}{*}{ غير دالة . . . . } & \multirow[t]{3}{*}{. TrV } & $r, 1 r$. & r & $\{7, Y 7\}$ & بين المجموعات & \multirow[t]{3}{*}{ الدرجة الكلية } \\
\hline & & $9 V, 70 \varepsilon$ & 19 & ᄉ791, IV\& & داخل المجموعات & \\
\hline & & $r \Lambda, r q \Lambda$ & r & $07, \vee 97$ & الكلي & \\
\hline
\end{tabular}


يتضح من الجدول السابق أنه: توجد فروق دالة إحصائياً عند مستوى ثقة ا ., . في مستوى فقدان السيطرة كبعد من أبعاد الاغتراب الوظيفي

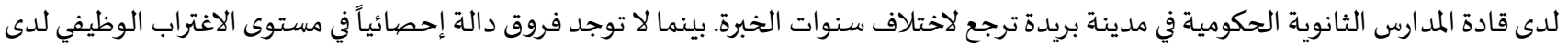

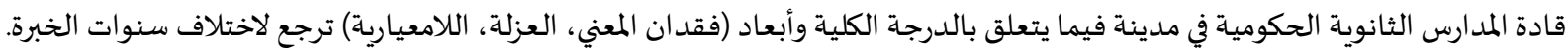
والنتائج هنا تؤكد في مجملها أن لسنوات الخبرة تأثير فقط على فقدان السيطرة كمؤشر للاغتراب الوظيفي لدى قادة المدارس الثانوية الحكومية في بريدة، وللكشف عن الفروق بين القادة مختلفي سنوات الخبرة في مستوى فقدان السيطرة تم استخدام اختبار شيفية Scheffe كاختبار للمقارنات

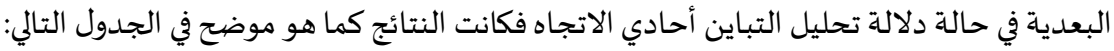

\begin{tabular}{|c|c|c|}
\hline من ه إلى أقل من • | (م= AVO, . I) & 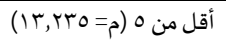 & سنوات الخبرة \\
\hline$\ldots$ & $* *$ **,rч. & من ه إلى أقل من • ا (م= AVO, . I) \\
\hline 1,rTr & $1,1 \mathrm{rV}$ & 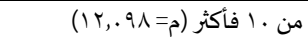 \\
\hline
\end{tabular}

ومن الجدول السابق يتضح أن أعلى المجموعات في الشعور بفقدان السيطرة هي المجموعة منخفضة سنوات الخبرة (أقل من 0 سنوات) حيث

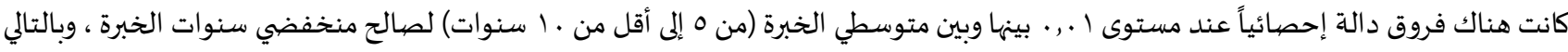

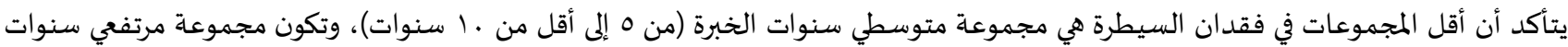

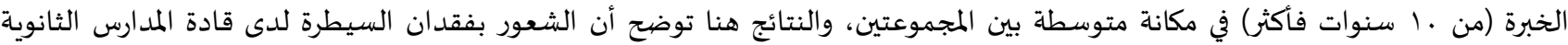

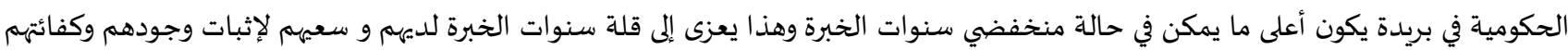

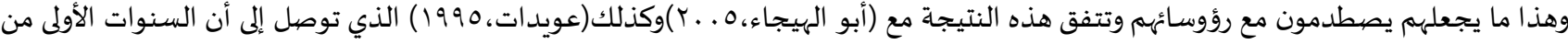

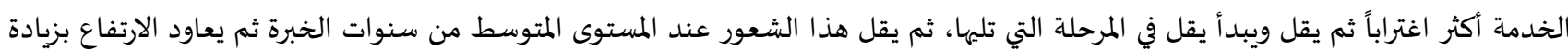

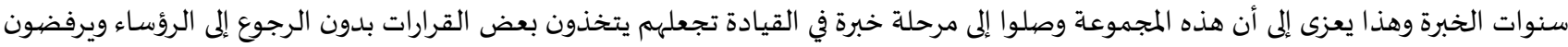

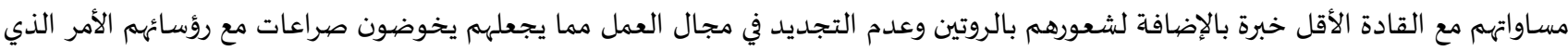

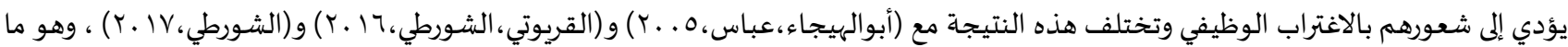
يتضح من الشكل التالي:

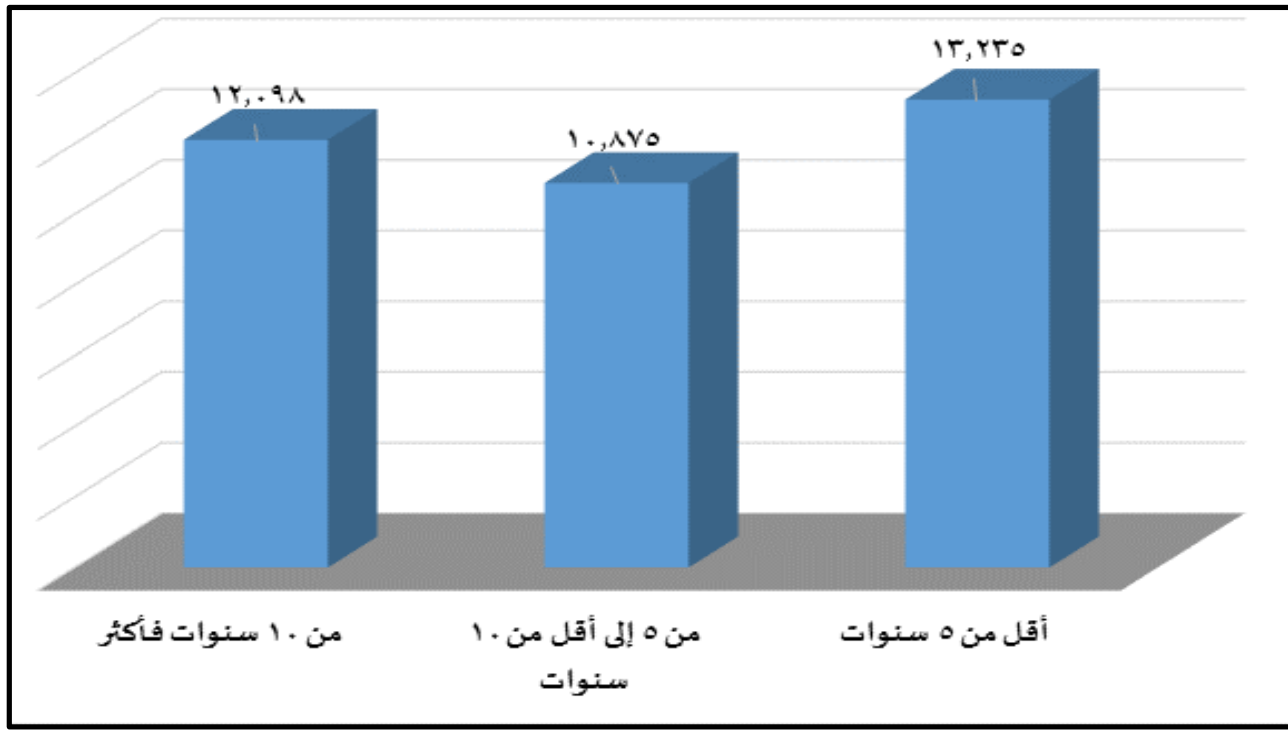

شكل (9): الفروق في فقدان السيطرة كبعد من أبعاد الاغتراب الوظيفي لدى قادة المدارس الثانوية الحكومية ببريدة

ا. العمل على خفض مستوى الاغتراب الوظيفي لدى قادة المدارس من خلال خلق بيئة عمل قائمة على إشراك القادة مع الرؤساء في عمليات التخطيط واتخاذ القرارات، وإيجاد نوع من اللامركزية في عمليات القيادة. r. التمكين الإداري للقادة خاصة القادة ذوي الخبرة من خلال إعطاءهم الحرية والاستقلالية في أداء الأعمال واتخاذ القرارات وعدم الرجوع للرؤساء في جميع الأمور. r. تطبيق نظام للحوافز قائم على أسس ومعايير موضوعية عادلة غير قائمة على المحسوبيات. 
ع. العمل على تعزيز الاتجاهات الإيجابية وبناء علاقات إنسانية وزيادة التفاعل الاجتماعي من خلال اللقاءات المستمرة والنشاطات الاجتماعية بين

القادة والرؤساء.

ه. العمل على توضيح القوانين واللوائح والأنظمة للقادة الجدد ودعمهم في تنفيذ المهام الوظيفية من خلال إقامة الدورات التدرببية وورشات العمل.

المقترحات البحثية: - مات

في ضوء النتائج والتوصيات والمستجدات فئيهات المجال التربوي بالمملكة تقترح الباحثة الدراسات التالية: ا. أثر تطبيق اللائحة الجديدة لأعضياء هيئة التدريس في الجامعات على الاغتراب الوظيفي.

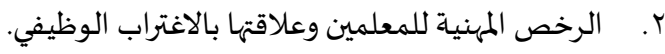
r. أثأثير العمل عن بعد على الاغتراب الوظيفي.

ع. مدى تأثير الاغتراب الوظيفي في بيئات العمل المختلطة حلى العديثاً.

المراجع:

أولاً: المراجع العربية:

ا. بحري، صابر. (9 . .ب). "الإجهاد المهني وعلاقته بالاغتراب المهني لدى الأطباء لدى الأطباء العاملون بالمستشفيات العمومية". رسالة ماجستير(غير منشورة)، في علم النفس تنظيم وعمل. جامعة متنوري بقسنطينة. الجزائر.

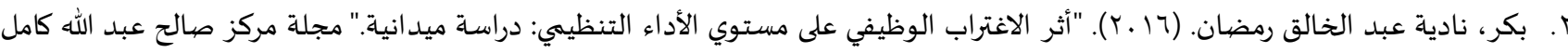

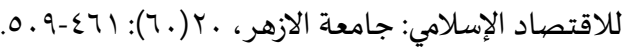

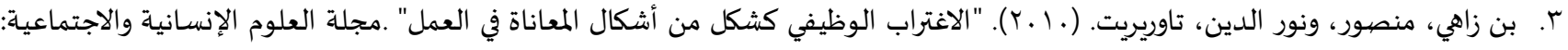

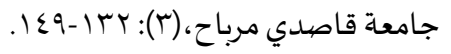
ع. تاميدي،كرين. (rا • †). "أثر التمكين النفسي في الاغتراب الوظيفي: دراسة استطلاعية لآراء رؤساء الأقسام العلمية في جامعة دهوك". تنمية الرافدين.

ه. تخة، خديجة، و مزيانى الوناس. (10 •ب). "الاغتراب الوظيفي لدي العمال ذوي الضبط الداخلي: دراسة استكشافية بمديرية التجارة بورقلة".

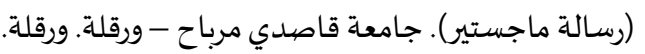

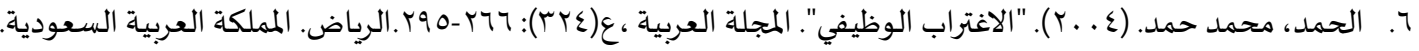

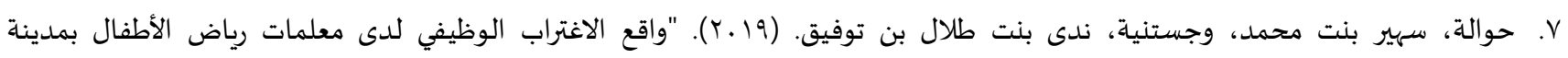

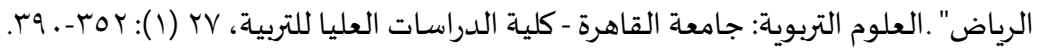

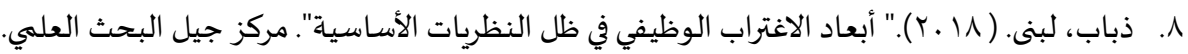

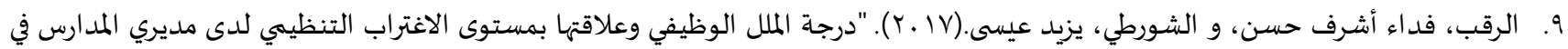
عمان" (رسالة ماجستير غير منشورة).

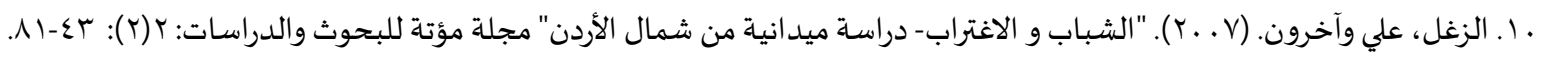

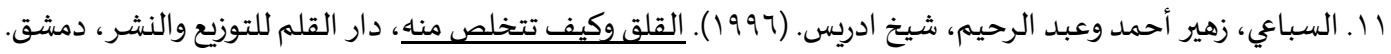

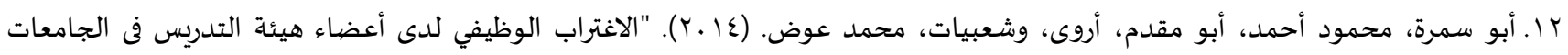

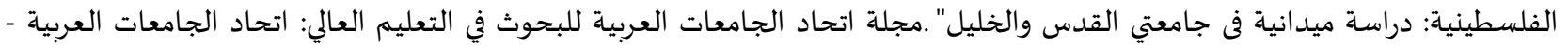

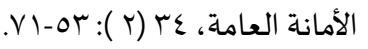
ץ ا. أبو سن، أحمد إبراهيم. (1991). الإدارة في الإسلام. عالم الكتب للنشر والتوزيع. القاهرة.

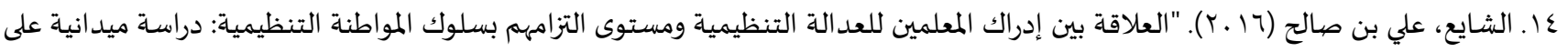

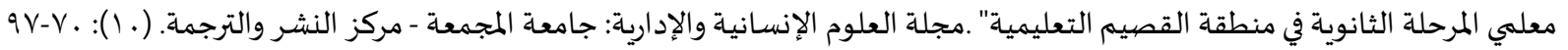
0 ا. شبات، جلال إسماعيل. (r ا ـ †). "الاغتراب الوظيفي وعلاقته بالمتغيرات الشخصية في الجامعات الفلسطينية"، جامعة القدس المفتوحة. فلسطين.

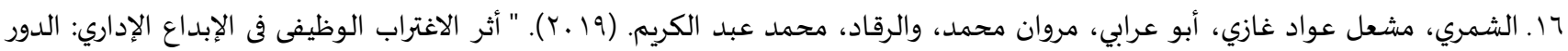
الوسيط للتمكين - دراسة تطبيقية في المصارف الكويتية". (رسالة دكتوراه غير منشورة). جامعة العلوم الإسلامية العالمية. عمان.

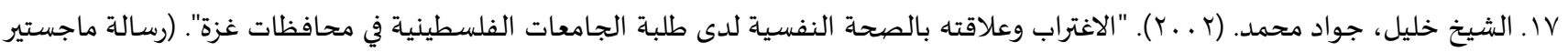
غير منشورة). معهد البحوث والدراسـات العربية. القاهرة. 


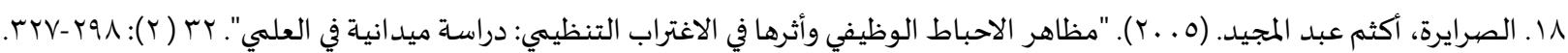
19. عادل، صادق. (1997). الألم النفسي والعضيوي. دار الأهرام. القاهرة.

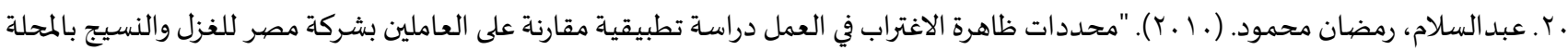
الكبريكلية التجارة". جامعة طنطا. مصر.

ا r. عبد المختار، محمد خضر. (1991) ). الاغتتراب والتطور نحو العنف. طبعة أولى. القاهرة. دار غريب للنشر والتوزيع. r r. العزاوي، سامي فياض. (. ا ـr). "الاغتراب الوظيفي وأثره في الانتاج العلمي: دراسة حالة في الجامعات الأردنية" .المؤتمر العربي الثاني: تنمية الموارد

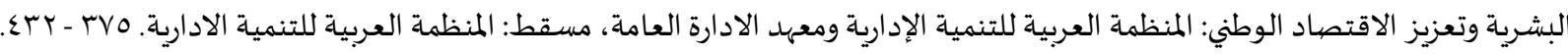
بr. عمران، محمد عبد الجواد. (7991). "أثر المناخ التنظيمي على عملية تطوير الموارد البشرية: دراسة مقارنة بالتطبيق على قطاع البنوك التجارية المصرية". (رسالة ماجستير غير منشورة). كلية الإدارة والتكنولوجيا. الأكاديمية العربية للعلوم والتكنولوجيا. القاهرة.

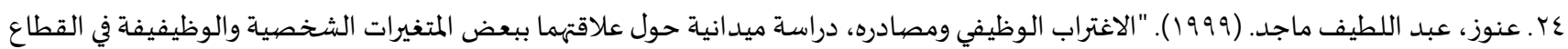

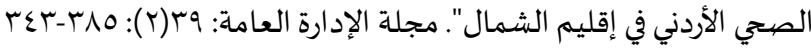
0. عويدات، عبد الله احمد. (1990). "مظاهر الاغتراب عند معلمي المرحلة الثانوية في الأردن" .دراسات - العلوم الإنسانية: الجامعة الأردنية - عمادة

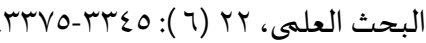

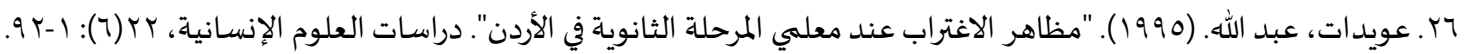
VY V. العيسوي،عبد الرحمن محمد. (199V). علم النفس والإنتاج. الدار الجامعية للنشر والتوزيع. الإسكندرية.

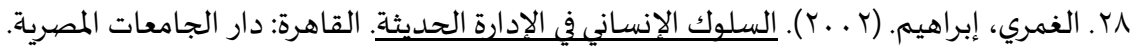

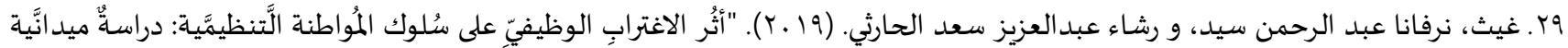

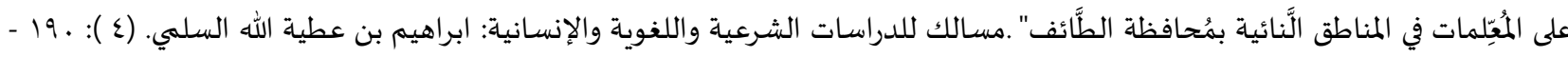
. $\varepsilon$.

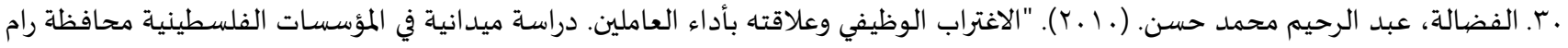

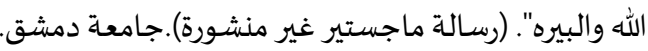

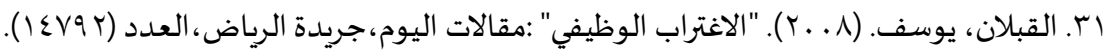

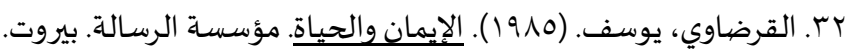

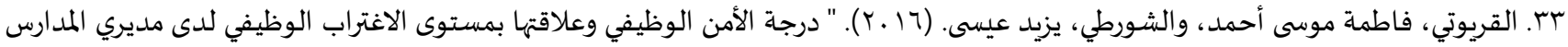

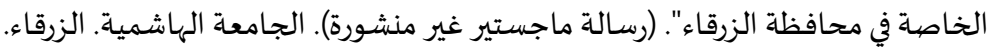
عץ. الكبيسي،عامر خضير حميد. (ع . .ب). "سيكولوجية التدريب: الاستراتيجيات والتقنيات والاشكاليات". مركز الدراسات والبحوث. جامعة نايف

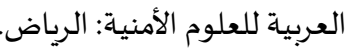

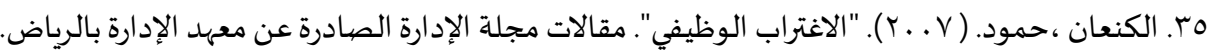
بr. الكنعان، حمود بن صالح. (1 (1 ـ). "تحديد العوامل المفسرة للعلاقة بين المستوى التنظيمي ومستوى الاغتراب الوظيفي" .مجلة العلوم الاجتماعية:

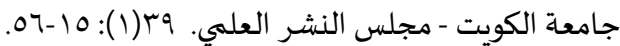
YV. المطرفي، شعيل غيث. (0. . †). "الاغتراب وعلاقته بالأداء: دراسة مسحية على العاملين بالإدارة جوازات منطقة مكة المكرمة". (رسالة ماجستير)،جامعة نايف للعلوم الأمنية. الرياض. لماض.

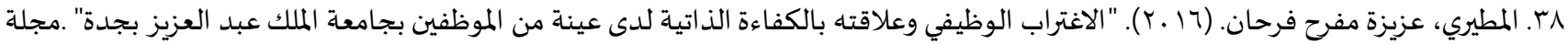

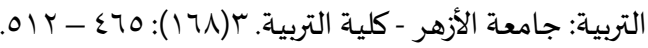
qr. موسى، وفاء. (Y . . Y). "الاغتراب لدى طلبة جامعة دمشق وعلاقتا بمدى تحقيق حاجتهم النفسية". (رسالة ماجستير غير منشورة). جامعة دمشق.

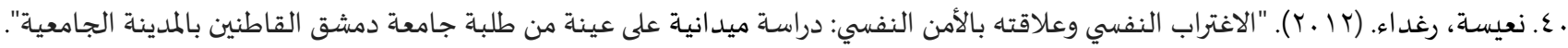

مجلة جامعة دمشق.

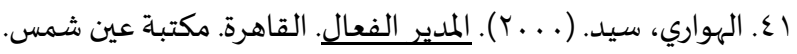

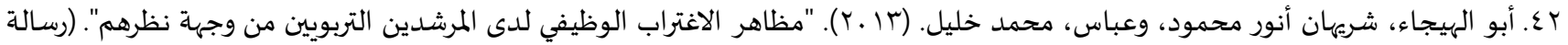
ماجستير غير منشورة). جامعة عمان العربية. عمان. 
[1] Awang, A. (2017). "Work alienation intervention in job-related tension, role overload and work effort". Revista De Administração De Roraima, 7(2): 268-296. https://doi.org/10.18227/2237-8057rarr.v7i2.4176.

[2] Çetinkanat, A. C., \& Kösterelioglu, M. A. (2016). "Relationship between quality of work life and work alienation: Research on teachers". Universal Journal of Educational Research, 4(8): 1778-1786. https://doi.org/10.13189/ujer.2016.040806.

[3] Erdem, M. (2014). "The level of quality of work life to predict work alienation". Educational Sciences: Theory and Practice, 14(2): 534-544. https://doi.org/10.12738/estp.2014.2.2126.

[4] Erikson, Erik H. (1968). “Identity: Youth and Crisis”, W. W. Norton,

[5] Keniston, Kenneth (1965). "The uncommitted: alienated youth in American Societ", Harcourt, Brace \& World,

[6] Verma, S. (2017). "Feeling of work alienation among primary school teachers". Journal of Psychosocial Research, 12(2): 469-476. 
المجلة الدولية للدراسـات التربوية والنفسية

International Journal of Educational \& Psychological Studies (EPS)

Journal Homepage: https://www.refaad.com/views/EPSR/Home.aspx

www.refaad.com

\title{
The level of job alienation among leaders of the public secondary schools in the city of Buraidah
}

\author{
Amlak Suliman Al-Sallal \\ Qassim University, KSA \\ malaksallal@hotmail.com
}

Ali Saleh Al-Shay'a

Professor of Administration and Educational Planning, Qassim University, KSA

\begin{abstract}
Received : 21/4/2020 Revised : 30/4/2020 Accepted : 11/5/2020 DOI : https://doi.org/10.31559/EPS2021.9.1.9
\end{abstract}
Abstract: The aim of the study is to identify the level of job alienation among the leaders of government secondary schools in the secondary stage in Buraidah, Saudi Arabia with different variables, and to achieve the goals of the study, the researcher adopted the descriptive approach, and the research sample consisted of (92) male and female leaders of the high school leaders in Buraidah, the researcher used the Blauner scale (1962) for job alienation with adjustments to it, and it was applied to the sample after confirming its reliability and consistent, and the research reached a set of results, including the fact that the level of job alienation among leaders came to a moderate degree, with an average (2.62) ), and in Percent(52\%), the dimension of loss of control was ranked first among the scale of dimensions, with an average of (2.99), and percentage of (60\%) with an average degree of verification, followed in the order by the non-standard dimension, with an average (2.77), percentage of (55\%), average degree of verification, and in the third order came after isolation, with a mean (2.57), percentage of (51\%), poor degree of verification, and the meaning loss dimension ranked fourth and last, with an average Mathematical (2.16), percentage of (43\%), and poor degree of verification. The results also revealed that there were statistically significant differences in the estimates of the research sample for the level of job alienation according to the gender variable, where the differences were for males at the total degree, and after loss of control and non-normality, while the results did not reveal statistically significant differences according to the variable of experience on the overall degree and on the dimensions of the tool except after losing control, where the differences in favor of those with experience were less than (5) years, compared to those with experience from (5) years to less than (10) years.

\section{Keywords: Alienation; Job Alienation; Isolation; Loss of meaning.}

\section{References:}

[1] 'adl, Sadq. (1996). Alalm Alnfsy Wal'dwy. Dar Alahram. Alqahrh.

[2] 'bdalslam, Rmdan Mhmwd. (2010). "Mhddat Zahrh Alaghtrab Fy Al'ml Drash Ttbyqyh Mqarnh 'la Al'amlyn Bshrkh Msr Llghzl Walnsyj Balmhlh Alkbraklyh Altjarh". Jam't Tnta. Msr.

[3] 'bd Almkhtar, Mhmd Khdr. (1998). Alaghtrab Walttwr Nhw Al'nf. Tb'h Awla. Alqahrh. Dar Ghryb Llnshr Waltwzy'.

[4] 'mran, Mhmd 'bd Aljwad. (1996). "Athr Almnakh Altnzymy 'la 'mlyt Ttwyr Almward Albshryh: Drash Mqarnh Balttbyq 'la Qta' Albnwk Altjaryh Almsryh". (Rsalt Majstyr Ghyr Mnshwrh). Klyt Aledarh Waltknwlwjya. Alakadymyh Al'rbyh Ll'lwm Waltknwlwjya. Alqahrh.

[5] 'nwz, 'bd Alltyf Majd. (1999). "Alaghtrab Alwzyfy Wmsadrh, Drash Mydanyh Hwl 'laqthma Bb'd Almtghyrat Alshkhsyh Walwzyfyfh Fy Alqta' Alshy Alardny Fy Eqlym Alshmal". Mjlt Aledarh Al'amh: 39(2): 385-343.

[6] 'wydat, 'bd Allh Ahmd. (1995). "Mzahr Alaghtrab 'nd M'lmy Almrhlh Althanwyh Fy Alardn". Drasat - Al'lwm Alensanyh: Aljam'h Alardnyh - 'madh Albhth Al'lma, 22 (6): 3345-3375. 
[7] 'wydat, 'bd Allh. (1995). "Mzahr Alaghtrab 'nd M'lmy Almrhlh Althanwyh Fy Alardn". Drasat Al'lwm Alensanyh, 22(6): 192.

[8] Al'yswy,'bd Alrhmn Mhmd. (1997). 'Im Alnfs Walentaj. Aldar Aljam'yh Llnshr Waltwzy'. Aleskndryh.

[9] Al'zawy, Samy Fyad. (2010). "Alaghtrab Alwzyfy Wathrh Fy Alantaj Al'lmy: Drash Halh Fy Aljam'eat Alardnyh". Alm'tmr Al'rby Althany: Tnmyt Almward Albshryh Wt'zyz Alaqtsad Alwtny: Almnzmh Al'rbyh Lltnmyh Aledaryh Wm'hd Aladarh Al'amh, Msqt: Almnzmh Al'rbyh Lltnmyh Aladaryh. 375 - 432.

[10] Bhry, Sabr. (2009). "Alejhad Almhny W'laqth Balaghtrab Almhny Lda Alatba' Lda Alatba' Al'amlwn Balmstshfyat Al'mwmyh". Rsalt Majstyr (Ghyr Mnshwrh), Fy 'lm Alnfs Tnzym W'ml. Jam't Mtnwry Bqsntynh. Aljza'r.

[11] Bkr, Nadyh 'bd Alkhalq Rmdan. (2016). "Athr Alaghtrab Alwzyfy 'la Mstwy Alada' Altnzymy: Drash Mydanyh." Mjlt Mrkz Salh 'bd Allh Kaml Llaqtsad Aleslamy: Jam't Alazhr, 20(60): 461-509.

[12] Bn Zahy, Mnswr, Wnwr Aldyn, Tawryryt. (2010). "Alaghtrab Alwzyfy Kshkl Mn Ashkal Alm'anah Fy Al'ml". Mjlt Al'lwm Alensanyh Walajtma'yh: Jam't Qasdy Mrbah,(3): 132-149.

[13] Dbab, Lbna. (2018)." Ab'ad Alaghtrab Alwzyfy Fy Zl Alnzryat Alasasyh". Mrkz Jyl Albhth Al'lmy.

[14] Alfdalh, 'bd Alrhym Mhmd Hsn. (2010). "Alaghtrab Alwzyfy W'laqth Bada' Al'eamlyn. Drash Mydanyh Fy Alm'ssat Alflstynyh Mhafzh Ram Allh Walbyrh". (Rsalt Majstyr Ghyr Mnshwrh).Jam't Dmshq.

[15] Alghmry, Ebrahym. (2002). Alslwk Alensany Fy Aledarh Alhdythh. Alqahrh: Dar Aljam'at Almsryh.

[16] Ghyth, Nrfana 'bd Alrhmn Syd, W Rsha' 'bdal'zyz S'd Alharthy. (2019). "Athur Alaghtrab. Alwzyfy.'la Sulwk Almuwatnh Altnzymý: Drashun Mydaný 'la Almu'elmat Fy Almnatq Alna'yh Bmuhafzh Altáf". Msalk Lldrasat Alshr'eyh Wallghwyh Walensanyh: Abrahym Bn 'tyh Allh Alslmy. (4): 190 - 240.

[17] Alhmd, Mhmd Hmd. (2004). "Alaghtrab Alwzyfy". Almjlh Al'rbyh ,'(324): 266-295.Alryad. Almmlkh Al'rbyh Als'wdyh.

[18] Hwalh, Shyr Bnt Mhmd, Wjstnyh, Nda Bnt Tlal Bn Twfyq. (2019). "Waq' Alaghtrab Alwzyfy Lda M'lmat Ryad Alatfal Bmdynt Alryad". Al'lwm Altrbwyh: Jam't Alqahrh - Klyt Aldrasat Al'lya Lltrbyh, 27 (1): 352-390.

[19] Alhwary, Syd. (2000). Almdyr Alf'al. Alqahrh. Mktbt 'yn Shms.

[20] Abw Alhyja', Shryhan Anwr Mhmwd, W'bas, Mhmd Khlyl. (2013). "Mzahr Alaghtrab Alwzyfy Lda Almrshdyn Altrbwyyn Mn Wjht Nzrhm". (Rsalt Majstyr Ghyr Mnshwrh). Jam't 'man Al'rbyh. 'Eman.

[21] Alrqb, Fda' Ashrf Hsn, W Alshwrty, Yzyd 'ysa.(2017). "Drjt Almll Alwzyfy W'laqtha Bmstwa Alaghtrab Altnzymy Lda Mdyry Almdars Fy 'man" (Rsalt Majstyr Ghyr Mnshwrh).

[22] Alkbysy,'amr Khdyr Hmyd. (2004). "Sykwlwjyh Altdryb: Alastratyjyat Waltqnyat Walashkalyat". Mrkz Aldrasat Walbhwth. Jam't Nayf Al'rbyh Ll'lwm Alamnyh: Alryad.

[23] Alkn'an ,Hmwd. ( 2007). "Alaghtrab Alwzyfy". Mqalat Mjlt Aledarh Alsadrh 'n M'hd Aledarh Balryad.

[24] Alkn'an, Hmwd Bn Salh. (2011). "Thdyd Al'ewaml Almfsrh Ll'laqh Byn Almstwa Altnzymy Wmstwa Alaghtrab Alwzyfy". Mjlt Al'lwm Alajtma'yh: Jam't Alkwyt - Mjls Alnshr Al'lmy. 39(1): 15-56.

[25] Almtrfy, Sh'yl Ghyth. (2005). "Alaghtrab W'laqth Balada': Drash Mshyh 'la Al'amlyn Baledarh Jwazat Mntqh Mkh Almkrmh". (Rsalt Majstyr),Jam't Nayf Ll'lwm Alamnyh. Alryad.

[26] Almtyry, 'zyzh Mfrh Frhan. (2016). "Alaghtrab Alwzyfy W'elaqth Balkfa'h Aldatyh Lda 'ynh Mn Almwzfyn Bjam't Almlk 'bd Al'zyz Bjdh". Mjlt Altrbyh: Jam't Alazhr - Klyt Altrbyh. 3(168): 465 - 512.

[27] Mwsa, Wfa'. (2002). "Alaghtrab Lda Tlbh Jam't Dmshq W'laqth Bmda Thqyq Hajthm Alnfsyh". (Rsalt Majstyr Ghyr Mnshwrh). Jam't Dmshq.

[28] N'eysh, Rghda'. (2012). "Alaghtrab Alnfsy W'laqth Balamn Alnfsy: Drash Mydanyh 'la 'ynh Mn Tlbt Jam't Dmshq Alqatnyn Balmdynh Aljam'yh". Mjlt Jam't Dmshq.

[29] Alqblan, Ywsf. (2008). "Alaghtrab Alwzyfy": Mqalat Alywm,Jrydh Alryad,Al'dd (14792).

[30] Alqrdawy, Ywsf. (1985). Aleyman Walhyah. M'sst Alrsalh. Byrwt.

[31] Alqrywty, Fatmh Mwsa Ahmd, Walshwrty, Yzyd 'ysa. (2016). " Drjt Alamn Alwzyfy W'laqtha Bmstwa Alaghtrab Alwzyfy Lda Mdyry Almdars Alkhash Fy Mhafzt Alzrqa'". (Rsalt Majstyr Ghyr Mnshwrh). Aljam'h Alhashmyh. Alzrqa'.

[32] Alsba'y, Zhyr Ahmd W'bd Alrhym, Shykh Adrys. (1996). Alqlq Wkyf Ttkhls Mnh, Dar Alqlm Lltwzy' Walnshr, Dmshq.

[33] Alshay', 'ly Bn Salh (2016). "Al'laqh Byn Edrak Alm'lmyn Ll'dalh Altnzymyh Wmstwa Altzamhm Bslwk Almwatnh Altnzymyh: Drash Mydanyh 'la M'lmy Almrhlh Althanwyh Fy Mntqh Alqsym Alt'lymyh". Mjlt Al'lwm Alensanyh Waledaryh: Jam't Almjm'h - Mrkz Alnshr Waltrjmh. (10): 70-97

[34] Shbat, Jlal Esma'yl. (2012). "Alaghtrab Alwzyfy W'laqth Balmtghyrat Alshkhsyh Fy Aljam'at Alflstynyh",Jam't Alqds Almftwhh. Flstyn. 
[35] Alshmry, Msh'l 'wad Ghazy, Abw 'raby, Mrwan Mhmd, Walrqad, Mhmd 'bd Alkrym. (2019). " Athr Alaghtrab Alwzyfa Fa Alebda'e Aledary: Aldwr Alwsyt Lltmkyn - Drash Ttbyqyh Fy Almsarf Alkwytyh". (Rsalt Dktwrah Ghyr Mnshwrh). Jam't Al'lwm Aleslamyh Al'almyh. 'man.

[36] Alshykh Khlyl, Jwad Mhmd. (2002). "Alaghtrab W'laqth Balshh Alnfsyh Lda Tlbt Aljam'at Alflstynyh Fy Mhafzat Ghzh". (Rsalt Majstyr Ghyr Mnshwrh). M'hd Albhwth Waldrasat Al'rbyh. Alqahrh.

[37] Abw Smrh, Mhmwd Ahmd, Abw Mqdm, Arwa, Wsh'byat, Mhmd 'wd. (2014). "Alaghtrab Alwzyfy Lda A'da' Hy't Altdrys Fa Aljam'at Alflstynyh: Drash Mydanyh Fa Jam'ty Alqds Walkhlyl". Mjlt Athad Aljam'at Al'rbyh Llbhwth Fy Alt'lym Al'ealy: Athad Aljam'at Al'rbyh - Alamanh Al'amh, 34 (2 ): 53-71.

[38] Abw Sn, Ahmd Ebrahym. (1991). Aledarh Fy Aleslam. 'alm Alktb Llnshr Waltwzy'. Alqahrh.

[39] Alsrayrh, Akthm 'bd Almjyd. (2005). "Mzahr Alahbat Alwzyfy Wathrha Fy Alaghtrab Altnzymy: Drash Mydanyh Fy Al'lmy". 32 (2): 298-327.

[40] Tamydy,Kryn. (2013). "Athr Altmkyn Alnfsy Fy Alaghtrab Alwzyfy: Drash Asttla'yh Lara' R'sa' Alaqsam Al'Imyh Fy Jam't Dhwk". Tnmyt Alrafdyn.

[41] Tkhh, Khdyjh, W Mzyana Alwnas. (2015). "Alaghtrab Alwzyfy Ldy Al'mal Dwy Aldbt Aldakhly: Drash Astkshafyh Bmdyryt Altjarh Bwrqlh". (Rsalt Majstyr). Jam't Qasdy Mrbah - Wrqlh. Wrqlh.

[42] Alzghl, 'ly Wakhrwn. (2007). "Alshbab W Alaghtrab- Drash Mydanyh Mn Shmal Alardn" Mjlt M'th Llbhwth Waldrasat: 2(2): 43-81. 